\title{
Technological Ecological Momentary Assessment Tools to Study Type 1 Diabetes in Youth: Viewpoint of Methodologies
}

Mary Katherine Ray ${ }^{1}, \mathrm{PhD}$; Alana McMichael ${ }^{1}, \mathrm{MA}$, MRSO; Maria Rivera-Santana ${ }^{1}$; Jacob Noel ${ }^{1}$, BA; Tamara Hershey $^{2}, \mathrm{PhD}$

${ }^{1}$ Department of Psychiatry, Washington University in St. Louis, St. Louis, MO, United States
${ }^{2}$ Department of Psychiatry, Mallinckrodt Institute of Radiology, Washington University in St. Louis, St. Louis, MO, United States

Corresponding Author:

Mary Katherine Ray, PhD

Department of Psychiatry

Washington University in St. Louis

4525 Scott Ave, East Bldg

St. Louis, MO, 63110

United States

Phone: 13143625041

Email: m.ray@wustl.edu

\section{Abstract}

Type 1 diabetes (T1D) is one of the most common chronic childhood diseases, and its prevalence is rapidly increasing. The management of glucose in T1D is challenging, as youth must consider a myriad of factors when making diabetes care decisions. This task often leads to significant hyperglycemia, hypoglycemia, and glucose variability throughout the day, which have been associated with short- and long-term medical complications. At present, most of what is known about each of these complications and the health behaviors that may lead to them have been uncovered in the clinical setting or in laboratory-based research. However, the tools often used in these settings are limited in their ability to capture the dynamic behaviors, feelings, and physiological changes associated with T1D that fluctuate from moment to moment throughout the day. A better understanding of T1D in daily life could potentially aid in the development of interventions to improve diabetes care and mitigate the negative medical consequences associated with it. Therefore, there is a need to measure repeated, real-time, and real-world features of this disease in youth. This approach is known as ecological momentary assessment (EMA), and it has considerable advantages to in-lab research. Thus, this viewpoint aims to describe EMA tools that have been used to collect data in the daily lives of youth with T1D and discuss studies that explored the nuances of T1D in daily life using these methods. This viewpoint focuses on the following EMA methods: continuous glucose monitoring, actigraphy, ambulatory blood pressure monitoring, personal digital assistants, smartphones, and phone-based systems. The viewpoint also discusses the benefits of using EMA methods to collect important data that might not otherwise be collected in the laboratory and the limitations of each tool, future directions of the field, and possible clinical implications for their use.

(JMIR Diabetes 2021;6(2):e27027) doi: 10.2196/27027

\section{KEYWORDS}

ecological momentary assessment; continuous glucose monitoring; actigraphy; accelerometer; ambulatory blood pressure monitoring; personal digital assistant; mobile phone; smartphone; mHealth

\section{General Introduction}

Type 1 diabetes (T1D) is one of the most common chronic childhood diseases with a rapidly rising incidence and prevalence [1,2]. It is an autoimmune disease characterized by the loss of insulin-producing $\beta$ cells of the pancreas, leading to an inability to use glucose as fuel, thus requiring life-saving exogenous insulin administration [3]. The management of glucose is challenging because patients must consider a myriad of factors when making diabetes care decisions (eg, insulin administration and glucose checks), such as the amount of carbohydrates consumed, insulin administered, physical activity, stress, illness, hormonal changes that cause natural spikes in glucose (eg, dawn phenomenon), and access to diabetes treatment technologies (eg, continuous glucose monitoring [CGM] and insulin pump) [4-6]. This complex web of factors and subsequent management decisions can lead to a significant amount of glucose variability throughout the day, with frequent 
fluctuations between normal (euglycemia), high (hyperglycemia), and low (hypoglycemia) glucose levels [4]. In fact, research has shown that young children with T1D are in a hyperglycemic state approximately $50 \%$ of the time [7] and experience thousands of hypoglycemic events in their lifetime [8]. These types of glycemic states have been shown to be associated with short- and long-term complications, including, but not limited to, hypoglycemia (sometimes severe), diabetic ketoacidosis (DKA), heart disease, retinopathy, nephropathy, neuropathy, sleep disturbances, and cognitive impairments [9-11].

At present, most of what is known about each of these complications and the health behaviors that may lead to them have been uncovered in the clinical setting or laboratory-based research using medical record data extraction, retrospective interviews asking participants to recall information from past events, and tests that measure health over extended periods (eg, hemoglobin $\left.\mathrm{A}_{1 \mathrm{c}}\left[\mathrm{HbA}_{1 \mathrm{c}}\right]\right)$. However, there are known limitations with measurements of this type, given their inability to capture the dynamic behaviors, feelings, and physiological changes associated with T1D that fluctuate from moment to moment throughout the day. Importantly, these measurements can also be confounded by recall bias [12], thus limiting our capacity to characterize and understand T1D. A better understanding of T1D in daily life could potentially aid in the development of behavioral and pharmaceutical interventions to improve diabetes care and mitigate the negative medical complications often associated with T1D. Therefore, there is a need to measure repeated, real-time, real-world features of T1D in daily life. This approach, known as ecological momentary assessment (EMA), can include a variety of methods, such as handheld computers, diaries, phones, smartphones, activity trackers, and physiological monitors (eg, CGM and ambulatory blood pressure monitoring [ABPM]) [12]. These methods can provide more valid ecological representations of patients' experiences, behaviors, and physiological measures with in-the-moment collection of information [12]. Fortunately, the widespread use of EMA is becoming more feasible because of the lower cost, greater familiarity, and usefulness of ambulatory technological devices such as smartphones and activity trackers (eg, Fitbit), especially in youth [13-15]. As a result, the use of wearable devices to collect real-world data is becoming increasingly popular across a variety of scientific fields to better understand disease states in a person's natural environment [16].

The use of EMA to understand factors related to T1D in daily life may be particularly important in youth, as they typically have more challenges with glycemic control than other age groups with diabetes [17] and are reaching developmental milestones that could impact their daily glucose management behaviors. For example, youth may behave differently with their T1D care if they are in a group of peers they feel the need to fit in with, or act differently, as they begin to seek independence from their parents [18]. Furthermore, it has been suggested that youth may not have yet developed the full cognitive abilities needed to integrate the information and skills needed to make appropriate management decisions [19]. This limitation could be even more concerning in patients with T1D, as a rich body of the literature has shown that acute complications (eg, severe hypoglycemia and DKA) and chronic hyperglycemia measured in the laboratory are associated with lower cognitive scores [11]. Furthermore, youth may still be unburdened by medical complications that often accompany T1D later in life. EMAs could potentially provide a more sensitive tool for early tracking of T1D complications that may not yet be detected in a clinical setting. Taken together, EMA methods could provide insight into important daily factors that influence T1D care behaviors and track physiological changes that may be predictive of complications in this particularly vulnerable population.

This viewpoint aims to describe EMA tools that have been used to collect data in the daily lives of youth with T1D and discuss studies that explored the nuances of T1D in daily life. This viewpoint focuses on several methods used to assess behavioral and physiological measures, including CGM, actigraphy, ABPM, personal digital assistants (PDAs), smartphones, and phone-based systems. The viewpoint also includes a discussion of the benefits of using EMA methods to collect important data that might not otherwise be collected in the laboratory and the limitations of each tool, future directions of the field, and possible clinical implications of using these tools.

\section{Overview of Methods Used to Identify and Assess EMA Tools}

The following keywords were searched using the PubMed database between January and September 2020: ("type 1 diabetes" and "ecological momentary assessment"), ("type 1 diabetes" and "EMA"), ("type 1 diabetes" and "actigraphy"), ("type 1 diabetes" and "field study"), ("type 1 diabetes" and "smartphone app"), ("type 1 diabetes" and "smartphone"), ("type 1 diabetes" and "phone"), ("type 1 diabetes" and "personal digital assistant"), ("type 1 diabetes" and "PDA"), ("type 1 diabetes" and "mHealth"), ("type 1 diabetes" and "mobile health"), ("type 1 diabetes" and "wearable"), ("type 1 diabetes" and "electronic health"), ("type 1 diabetes" and "eHealth"), ("type 1 diabetes" and "sleep"), ("type 1 diabetes" and "ambulatory"), ("type 1 diabetes" and "accelerometer"), ("type 1 diabetes" and "CGM"). Each pair of search terms was combined with "youth," "adolescent," and "children." Articles were reviewed starting in 2005, given the rapid development of technology, particularly real-time CGM, around this year.

To narrow the focus of the viewpoint, articles for the literature review portion of each section were not typically included in our synthesis of the literature if youth with T1D were not the primary study population (eg, articles combining all youth and adult data and articles focused on the caregivers of youth with T1D); the article was a review, case report, book chapter, editorial, conference abstract, study protocol, or comment; the article was written in a language other than English; the study was conducted in an animal model; the article did not directly seek to obtain EMA measures multiple times per day on a technological device; the study was conducted entirely in an in-lab setting; physical activity was the primary focus of an actigraphy study; or the article focused on flash glucose monitoring versus CGM. This viewpoint was intended to provide an overview of popular EMA tools to collect data in youth with 
T1D and provide a generally comprehensive but not exhaustive discussion of the articles that have used each tool.

\section{Viewpoint of Methodologies}

\section{Continuous Glucose Monitoring}

\section{Introduction}

It is becoming increasingly clear that $\mathrm{HbA}_{1 \mathrm{c}}$ has many limitations and is not the only important factor for measuring glycemic control and predicting the risk of medical complications in T1D [20]. Although glucose variability remains poorly understood, it has recently been highlighted as a potential risk factor for developing disease complications [21]. Understanding the importance of glucose variability is becoming much more feasible with the use of CGM technology, perhaps the most well-known EMA method used in T1D. Real-time CGMs typically measure interstitial glucose every 1-5 minutes via a sensor embedded under the skin, and information is then transmitted to a tracking device such as a smartphone app, receiver, or insulin pump [22-24]. Most current CGMs usually measure glucose every 5 minutes, with 288 measurements per day [24] compared with self-monitored blood glucose (SMBG), which is often only measured to test for hypoglycemia or in situations such as with meals, exercise, bedtime, or certain tasks (eg, driving). This can vary among participants but typically requires SMBG measurements 6-10 times per day [25]. Thus, the frequent testing of glucose with CGM provides a more comprehensive view of glucose patterns and variability over time compared with glucose snapshots provided by SMBG or $\mathrm{HbA}_{1 \mathrm{c}}$. Data collected via CGM can provide information on glucose trends, the amount of time a person is in a specified glucose range (eg, euglycemia: $70-180 \mathrm{mg} / \mathrm{dL}$ ), asymptomatic glycemic events, the amount of glycemic variability, the mean glucose over discrete periods (eg, 14 days), overnight glucose patterns - not typically captured with SMBG — and postprandial glucose peaks [22,25-29].

This more encompassing view of glucose patterns can aid health care providers in the development of optimized goals and plans aimed at improving glucose levels and mitigating negative medical complications [20]. CGM has also been shown to be empowering for youth with $\mathrm{T} 1 \mathrm{D}$, as it allows them to easily access data such that they can have more control over their glucose, provides motivation for dietary intake changes, and helps them manage hyper- and hypoglycemia [30]. As a result of these benefits, the use of CGM is increasing rapidly, especially in young children [31-33]. For example, CGM use in youth in a large diabetes registry increased from $4 \%$ to $31 \%$ between 2013 and 2017 [33].

\section{Literature Review}

\section{Using CGM to Identify Relationships Between Daily Factors and T1D Symptoms and Behaviors}

CGM data have been used to better help understand the relationship between daily activities, behaviors, and glucose control including diets and eating patterns [34-39], exercise or activities [40-50], sleep [51-53], amount of time spent at home (eg, before and during the COVID-19 lockdown) [54], and externalizing behaviors [55].

\section{Using CGM to Measure Outcomes}

Data collected with CGM have also provided an important tool for testing the feasibility and effectiveness of insulin delivery systems, insulin treatments, adjunctive diabetes medications, T1D screening, new glucose monitoring systems, algorithms for the promotion of improved glycemic control, sensor-augmented therapy algorithms, and closed-loop systems [56-91]; diabetes alert dogs [92]; education programs aimed at improving impaired hypoglycemia unawareness, daily therapy decisions, and cardiovascular health [93-95]; and use of glucose sharing data with others [96]. This technology has also been used to assess the relationship between continuous glucose measures and other diabetes-related outcomes, including long-term glycemic control, dysglycemia [97,98], future T1D diagnosis or dysglycemia in preclinical youth [99-101], $\mathrm{HbA}_{1 \mathrm{c}}$ [102-105], C-peptide [102], insulin sensitivity [106], severe hypoglycemia [107], time in target range [108-110], glucose variability [109-113], detection of hypo- or hyperglycemia [108-110,114-116], glycated albumin [104], fructosamine [104], and 1,5-anhydroglucitrol [104]. Furthermore, CGM has been used to determine the relationship between continuous glucose measures and other medical outcomes, including body composition [117], markers of inflammation [118], cardiovascular health [119], and brain health (eg, white matter integrity) [120].

\section{Using CGM to Improve T1D}

Thus far, there is substantial evidence to suggest that CGM use is associated with improved glycemic control, including lower or improved $\mathrm{HbA}_{1 \mathrm{c}}$, reaching target $\mathrm{HbA}_{1 \mathrm{c}}$ [121-146], decreased hyper- or hypoglycemic events or time in a hyper- or hypoglycemic state $[137,138,145-148]$, reduced SD or mean glucose $[134,146]$, reduced glucose variability [134,137,148], and increased time in the target glucose range [127,137,146]. CGM use has also been shown to be related to improved treatment and outcomes, including more advanced and optimized treatment recommendations by physicians to improve glycemic outcomes [149,150], increased satisfaction with diabetes treatment [123,151], improved perceived awareness of or hormonal responses to hypoglycemia $[123,152]$, reduced fear of hypoglycemia [153,154], reduced patient distress [139], and altered amount of insulin used per day (eg, both decreased and increased insulin use per day) [140,154]. Outside of direct diabetes outcomes, CGM use has been shown to be associated with a higher quality of life (when a new algorithm was used to help guide insulin administration) [155], improved school attendance [151], and increased comfort with diabetes management in the school setting [156].

Furthermore, studies have shown significant benefits of using CGM sensor-augmented pump therapy systems that can initiate automatic functions for suspending insulin in the event of current or predicted low-glucose and closed-loop systems. For example, predictive low-glucose suspension or hyperglycemia and hypoglycemia minimization functions have been shown to be related to improvements in $\mathrm{HbA}_{1 \mathrm{c}}$ [89], greater time in range [74], reduced mean glucose levels in the morning [74], reduced 
area under the curve for hypoglycemia and hyperglycemia (eg, $>240 \mathrm{mg} / \mathrm{dL}$ ), and hypoglycemia [67,69,70]. Closed-loop systems have also been shown to improve T1D, including lower mean glucose $[60,75,76,80,86]$, reduced frequency of hypoglycemia intervention $[60,80]$, lower proportion of time or less time in hypoglycemia $[68,72,80]$, and increased time in range or time in tight range of control $(80-140 \mathrm{mg} / \mathrm{dL})$ $[68,75,76,85,86]$. Furthermore, youth have expressed positive experiences with closed-loop systems, including self-reported positive impact on sleep, their routines, and safety [157]. Interestingly, a study evaluated the ability of a heart rate monitor to inform closed-loop system decisions with exercise and found that the incorporation of heart rate data into the closed-loop system improved time below a glucose level of $70 \mathrm{mg} / \mathrm{dL}$ even though it did not reduce the number of hypoglycemic events [48]. When comparing the 2 types of systems, studies have shown significant benefits for closed-loop systems versus sensor-augmented therapies with glucose suspend functions. For example, youth with closed-loop systems or control-to-range algorithms have been shown to have less time below the target range [71], reduced symptomatic hypoglycemia at night [71], increased time in range [75], and lower mean glucose [75].

Although there is a significant amount of evidence showing the benefits of CGM in improving T1D, it is important to note that not all studies have found statistically significant improvements in all measures between CGM users and CGM nonusers or with the initiation of CGM use across different time points and age groups $[126,129,138,140,148,153,154,158-166]$. The lack of evidence for the benefits of CGM could potentially be the result of the amount of time spent using the tool. For example, more and consistent use versus intermittent use, full compliance with the research protocol, age, baseline glycemic control, and self-efficacy with CGM use have all been suggested to be important factors for clinical improvements with CGM [56,122,124,131,132,134,140,148,159,161,167-169].

\section{Limitations of CGM}

It is clear that CGM has many advantages; however, there are limitations to its use. There is still the potential for measurement error, false alarms (eg, alert for hypoglycemia when the patient is euglycemic), alarms that do not awake patients at night [24,170-173], signaling loss-driven gaps in data, and data interpretation challenges [174]. The sensors can also be uncomfortable or painful or fall out, which is of significant concern given the high cost of the technology and difficulties with insurance coverage [24,171,173-179]. There can also be an annoyance or alarm fatigue with frequent alerts about glucose and sensor status, potentially causing patients to feel overwhelmed or embarrassed, especially in public environments [28,171,172,177,180-182]. Furthermore, the abundance of information provided by CGMs may cause anxiety, frustration, and self-thoughts of failure or that they have bad blood glucose patterns, especially if they have difficulty interpreting the substantial amount of data provided by CGM [24,28,174]. In the same vein, youth may fear chastisement from others (eg, parents and physicians) if they have frequent hypo- or hyperglycemic events that would not otherwise be observed with SMBG [24]. All these factors could significantly affect the adherence to CGM use. However, programs are being developed to help better teach youth how to overcome the challenges associated with CGM [183].

\section{CGM Conclusions}

Overall, frequent, repeated glucose measurements with CGM can provide great benefits over one-time snapshots of glucose. In addition to a significant enrichment of glucose information, CGMs could further enhance our knowledge of T1D when paired with other EMA methods to determine how in-the-moment behaviors are associated with subsequent glucose patterns and how glucose patterns relate to daily health (eg, sleep). CGM is growing in popularity among youth with T1D and has significant advantages over in-lab glucose measures or SMBG, as it provides a wealth of knowledge that can be used to better understand glucose fluctuations. However, there are still limitations to its use, such as inaccurate readings and discomfort, that need to be addressed in future technological development.

\section{Actigraphy}

\section{Introduction}

Actigraphy is a noninvasive, motion-sensing tool often worn on the wrist for extended periods to collect information about measures such as physical activity or sleep [184]. Sleep is of particular concern for youth with T1D, as research has shown consistent sleep disturbances compared with their peers without T1D [10], with an average of approximately 26 minutes less sleep per night [185]. Actigraphy provides numerous advantages over in-lab methods of collecting sleep data, as it is inexpensive and can be used to examine sleep patterns over multiple days [186-188]. Furthermore, it is relatively suitable for correctly identifying sleep periods in youth and can assess numerous facets of sleep (eg, sleep onset, sleep onset latency, frequency of nocturnal waking, duration of nocturnal waking, wake after onset, the midpoint of sleep, nap duration, total sleep period, wake time, total sleep time, sleep efficiency, fragmentation of sleep, and longest continuous sleep episodes) by repeatedly measuring movement and heart rate (with some, but not all trackers) [188]. Taken together, actigraphy offers an affordable and convenient method of measuring sleep at home, providing a unique means of collecting more information about how sleep is affected in the daily lives of youth with T1D.

\section{Literature Review}

\section{Using Actigraphy to Identify Relationships Between Daily Factors and T1D Symptoms and Behaviors}

Actigraphy has uncovered important relationships between sleep and diabetes care behaviors in daily life. For example, both average sleep duration and sleep variability have been shown to be associated with diabetes care behaviors (eg, less average sleep duration related to decreased SMBG or more sleep variability related to decreased SMBG) $[189,190]$. Furthermore, actigraphy-derived data have shown a relationship between $\mathrm{HbA}_{1 \mathrm{c}}$ and altered sleep (eg, more total sleep time related to lower $\mathrm{HbA}_{1 \mathrm{c}}$ ) [51,189], found a relationship between sleep in children and sleep in their parents [191], and showed that youth with T1D who have obesity may have different sleep patterns compared with patients with T1D without obesity [192]. 
Importantly, actigraphy has uncovered relationships between specific patterns of glucose control (eg, greater glucose variability, more time in hypoglycemia, and suboptimal $\mathrm{HbA}_{1 \mathrm{c}}$ ) and disrupted or variable sleep [53,193-195]. For example, Monzon et al [193] found that measures of sleep (eg, sleep onset latency and nighttime awakenings) predicted more variability in glucose on weekend days, highlighting the potential importance of maintaining consistent sleep routines throughout the week.

It is important to note that most of these studies were correlational and therefore could not determine the directionality of the relationship between sleep and glycemic control $[51,53,189,190,195]$. It has been suggested that there is bidirectionality in the relationship (eg, more glycemia outside of the recommended range increases the likelihood of hypoglycemia and hyperglycemia at night, which can then impair sleep [190]). Monzon et al [193] found a bidirectional association between glucose variability and awakenings on weekend nights, suggesting that youth with more weekend awakenings may have more glycemic variability in the following days and that youth may have more awakenings after weekend days where they have more glucose variability. They also suggest that future research considers how both physiology (eg, physiological changes in glucose) and behavior (eg, waking to check glucose at night) could explain the bidirectional relationship between glucose control and sleep [193].

\section{Using Actigraphy to Measure Outcomes}

Given that youth with T1D often have sleep impairments or do not meet current sleep recommendations [51,189,190,193-196], interventional strategies are needed to help improve sleep in this population; 2 recent studies found that smartphone app-based interventions improved sleep measured via actigraphy in youth with T1D. Jaser et al [197] found that their intervention improved sleep efficiency and increased total sleep time by approximately 48 minutes. Similarly, Perfect et al [198] found that their sleep intervention protocol increased actigraphy-measured sleep by approximately 29 minutes. These studies highlight the promise of mobile health (mHealth) interventions (ie, medical care supported by a mobile device) [199] to treat sleep in this vulnerable population. Furthermore, not only is actigraphy being used to assess whether these mHealth interventions can improve sleep, but it is also being used to determine whether new diabetes management systems (eg, hybrid closed-loop systems) can improve sleep among youth with T1D and their parents [200].

\section{Limitations of Actigraphy}

It is important to note that although actigraphy has been shown to be relatively sensitive in measuring sleep, not all studies have shown comparative results between actigraphy and the gold standard of sleep measurement — polysomnography — and it has been shown that actigraphy has low specificity for certain measures such as detection of wake after sleep onset [188]. It has been suggested that actigraphy may be a better tool for collecting typical sleep data and may be less reliable in adequately measuring disturbed sleep [186]. Furthermore, studies have used a wide range of tracking devices (eg, Fitbits and Actigraphs), which could potentially create discrepancies between results [188]. More tool development and validation testing are needed to measure sleep adequately, especially disrupted sleep.

\section{Actigraphy Conclusions}

Actigraphy is increasingly being used to assess sleep in youth with T1D. The EMA tool provides an inexpensive way to objectively measure sleep in the daily lives of youth in their natural environments. Studies have shown more sleep disturbances in youth with T1D, and these disturbances have also been shown to be related to important T1D self-care behaviors and glycemic control. Promising preliminary studies have shown the potential use of app-based interventions to improve sleep; however, more trials are needed. Furthermore, more validation testing and consistent tracker use should be considered in future studies.

\section{Ambulatory Blood Pressure Monitoring}

\section{Introduction}

Cardiovascular disease is a significant concern in patients with T1D. Unfortunately, in-office blood pressure measurements only capture a snapshot of blood pressure, which changes continuously throughout the day [201]. In-office monitoring is also influenced by masked hypertension (patients can have normal in-office blood pressure but elevated when measured 24 hours per day out of the office) and the white-coat phenomenon (patients have elevated blood pressure when measured in the office but have normal blood pressure in daily life) [202]. Specific to youth with T1D, 9.5\% have been shown to have masked high blood pressure, whereas $32 \%$ have been shown to have white-coat hypertension [203]. To mitigate these phenomena and better assess the impact of circadian rhythms on blood pressure, researchers and clinicians have turned to ABPM as a tool to collect EMA data on heart function [202,204,205]. Importantly, a more accurate determination of heart function using the EMA tool could lead to a more appropriate use of blood pressure medications [206]. ABPM is typically measured via an ambulatory blood pressure cuff every 15-20 minutes during the day and every 20-30 minutes at night (varying by study), providing a large amount of information on blood pressure and heart rate variability in varying contexts [201].

\section{Literature Review}

\section{Using ABPM to Measure Outcomes}

A large number of studies have used ABPM to measure cardiovascular function outcomes in youth with T1D and found that patients often have high blood pressure measures (eg, high systolic or diastolic pressure at different times of day), prehypertension, or higher blood pressure than their peers who do not have T1D [203,207-225], with higher blood pressure-measured with ABPM being predictive of future hypertension [220]. Many factors have been found to be associated with measures of high blood pressure in this population, including higher $\mathrm{HbA}_{1 \mathrm{c}}[208,209,215,226]$, age [209], sex [208,209], diabetes duration [208,209,214,225,226], unstable glycemic control [225], insulin dose [209,215,225], BMI [209,215,226], genetics [227,228], triglycerides [214], 
high salt intake [226], and selectins involved in inflammation (eg, E-selectin) [214,229].

People without T1D typically have a dip in nocturnal systolic and diastolic blood pressure by approximately 10\%-20\% from daytime blood pressure [201]. However, research using ABPM has consistently shown that patients with T1D often do not have this normal dip or have less dipping than youth without T1D [207,209,218,221,222,224,230-234]. This abnormal dipping has been shown to be related to age, sex (ie, being female associated with more abnormal dipping) [209], $\mathrm{HbA}_{1 \mathrm{c}}$ [209,226], higher ambulatory arterial stiffness-a potential marker of arterial stiffness to predict heart mortality [232], reduced 24-hour heart rate [233,234], reduced mean daytime heart rate [233,234], prolonged QT interval (interval from the Q to the T electrical wave), greater left ventricular end-diastolic and end-systolic diameters [233,234], greater left ventricular mass index [234], and specific heart oscillation patterns [235]. In addition, not only does high blood pressure present a problem in itself, but it is also associated with other negative medical complications. In fact, several studies have found a relationship between high blood pressure measures obtained with ABPM and markers of kidney damage or disease in youth with T1D [211,215,220,222,236-239].

Although there is substantial evidence for increased blood pressure in youth with T1D, not all studies have found robust, statistically significant relationships between diabetes and high blood pressure across contexts [240,241]. For example, Raes et al [240] found no significant difference in blood pressure between youth with T1D and those without T1D when participants were at rest but observed significantly higher blood pressure in patients with T1D while they were participating in exercise. Furthermore, not all studies have found a relationship between blood pressure and markers of kidney damage [218,242]. For example, Soltysiak et al [242] found no relationship between blood pressure and increases in neutrophil gelatinase-associated lipocalin, an early marker of kidney damage.

\section{Limitations of ABPM}

ABPM use in research is limited by the potential interference it presents with a patient's activities in daily life and inaccurate readings if the cuff is placed incorrectly during measurement [243]. Therefore, more research is needed to develop less intrusive and more valid devices or protocols. Furthermore, the nocturnal dipping status may not be consistently reproducible. Thus, it has been suggested that the focus of research is on 24-hour systolic blood pressure versus dipping status [206].

\section{ABPM Conclusions}

ABPM provides an excellent tool for measuring real-world heart function while avoiding potentially confounding variables, such as the white-coat phenomenon and masked hypertension, which might otherwise conceal heart function complications when measured in a laboratory setting. The use of this EMA method has uncovered important heart function complications in youth with T1D. Overall, blood pressure measurements obtained from ABPM have consistently been shown to be elevated in youth with T1D, and this increased blood pressure has been associated with markers of kidney damage. Thus, real-world testing could highlight the need to conduct earlier tracking of heart function and interventions in youth with T1D.

\section{Personal Digital Assistant}

\section{Introduction}

All of the EMA tools discussed so far have passively collected repeated, real-time data such that the patients did not consciously and purposefully have to interact with the device. To collect more information about a patient's conscious behavior or perceived experiences, more active EMA methods are needed, such as PDAs. PDAs are often referred to as handheld computers, as they can connect to the internet, be used to organize information, and communicate via email or a personal computer [244]. Although PDAs can function similarly to more recent technological developments (eg, smartphones), supplying PDAs to participants could help reduce limitations related to patients not having their own devices or owning devices that are not compatible with the study software.

\section{Literature Review}

\section{Using PDAs to Identify Relationships Between Daily Factors and T1D Symptoms and Behaviors}

Several studies have been conducted using PDAs to determine how environmental factors impact patient experiences and diabetes care behaviors in youth with T1D in real-world settings. For example, Helgeson et al [18] had patients complete periodic measures of interpersonal interactions (eg, had the participant had a social interaction? Was the interaction positive or negative?) and mood on a PDA throughout the day and found that less enjoyment and being upset from a social interaction predicted depressed mood and anxiety. PDA devices also found that patients were more likely to check their glucose when they reported a strong desire to blend in with their companions and less likely to check glucose when they wanted to impress people [245]. Taken together, the results suggest that peer relationships in daily life are associated with self-care behavior and psychological well-being in youth with T1D.

As described in the General Introduction, lower cognitive scores have been shown to be associated with severe hypoglycemic events, DKA, and chronic hyperglycemia when measured in a laboratory setting [11]; thus, it is important to understand how momentary cognitive function is related to T1D in daily life. Gonder-Fredrick et al [246] had patients use a PDA device to determine the relationship between SMBG and cognitive function (ie, mental math and reaction time task) in a real-world setting. Performance was worse during periods of hypoglycemia $(<54 \mathrm{mg} / \mathrm{dL})$ and hyperglycemia (>400 mg/dL) compared with euglycemia (although not statistically different for hyperglycemia and the reaction time task). Thus, mental efficiency is altered by hypo- and hyperglycemia in the daily lives of youths with T1D [246]. Importantly, it is possible that cognitive impairment is not only affected by glucose levels but may also affect subsequent glucose levels through poor T1D care decisions. More research is needed to better understand the complex relationship between glucose levels, cognitive impairment, and T1D care decisions. 


\section{Using PDAs to Measure Outcomes}

PDA devices have also provided important information on T1D outcomes in daily life. Gonder-Fredrick et al [247] assessed real-world glucose symptoms in which youths were asked to estimate their current blood sugar and rate symptoms on a PDA (with the help of a parent) immediately before measuring SMBG. The youths struggled to correctly estimate glucose, making clinically accurate estimates less than one-third of the time and did not detect $>40 \%$ of hypoglycemic episodes. Children less accurate in detecting low glucose levels also had more severe low blood sugar levels in the subsequent 6-month period. This inability to recognize hypoglycemia is problematic and suggests that more education may be needed to improve the detection of low glucose levels in this population [247].

\section{Limitations of PDA}

As with most EMA methods that require self-report, there can be uncertainty about the validity of the data, given that they are collected without researcher or clinician supervision [248]. Therefore, it is possible that someone other than the participant is completing the measure or that the patient is not fully dedicated to the task at hand. With the technological nature of PDAs, there is always the risk of software and hardware issues [12] (eg, poor connection to the system transmitting the data). Furthermore, as with most EMA studies, there is a significant concern with testing compliance [12] and dropping out when asked to use these devices in everyday life. Finally, PDAs may now be less available as they have been replaced with smartphones.

\section{PDA Conclusions}

PDAs have captured complex relationships and nuances that could significantly impact a patient's daily life, which might otherwise be lost if measured only in a clinical or laboratory setting. Several psychosocial and contextual factors have been found to be associated with T1D self-care behavior and psychological well-being, such as wanting to fit in and wanting to impress others. Research has also revealed information about T1D symptoms in the real world, including undetected hypoglycemia and impaired cognitive function. Information collected via PDAs could potentially help provide an avenue for directly addressing these factors to improve T1D management and treatment.

\section{Smartphone Apps and Phone-Based Systems}

\section{Introduction}

The use of phones to collect EMA data is becoming more feasible as their ownership in childhood and adolescence continues to increase. In those aged 8-12 years, phone ownership increased from $24 \%$ to $41 \%$ between 2015 and 2019, and in those aged 13-18 years, ownership increased from $67 \%$ to $84 \%$ [14]. Phone ownership has been shown to be even more common in youth with T1D, with a study reporting that over $92 \%$ of patients aged $\geq 12$ years $(n=279)$ carry a phone in their daily lives [249]. The increased feasibility provides an ideal window for the development of new assessment platforms using these tools. As with PDAs, phones can collect data in a variety of ways. For example, they can prompt participants with a notification to enter information at fixed or random intervals throughout the day, or patients could be instructed to upload diabetes information when applicable (eg, when they miss an insulin dose, they tell an app what was happening in their lives at the moment that led to the missed dose).

\section{Literature Review}

\section{Using Smartphone Apps and Phone-Based Systems to Identify Relationships Between Daily Factors and T1D Symptoms and Behaviors}

Researchers have developed several smartphone apps to collect EMAs in pursuit of assessing environmental factors related to T1D care behaviors. For example, the MyDay smartphone app developed by Mulvaney et al [250] was used to identify psychosocial and contextual factors that impact self-care behaviors (eg, SMBG and insulin administration) in youth with T1D and found that patients reported significant social and contextual barriers to T1D management, including being with family, friends, and alone, fatigue, hunger, having fun, and being in a rush. Importantly, some of the barriers were shown to be significantly associated with self-care behaviors (eg, fatigue was associated with more missed insulin administration) [250], highlighting the potential for tailored treatments to address specific environmental barriers.

Several apps and systems have also been developed that synchronize cellphones to glucometers, allowing patients to upload glucose readings to their phones (eg, SMBG and CGM readings) or synchronize their glucose to their parents' phones. These apps and systems have also been designed to include features that allow a patient to manually log blood glucose, carbohydrate intake, meals, exercise, medications, insulin pump basal and bolus settings, glucose trends, illness, or life events (eg, vacation), often providing users with an integrated view of the myriad of daily factors that could affect glycemic control. Several of the apps include chat rooms for youth with T1D to communicate with one another, functions that allow patients to contact health care providers, reminders for patients to participate in T1D self-care behaviors, insulin and carbohydrate calculators, tips for diabetes treatment, information about T1D, and gamification incentives for participating in diabetes self-care behaviors [19,251-266].

For example, the DiaMob app was partly developed to help patients understand carbohydrate counting and insulin dosing. Participants were asked to provide information about physical activity around mealtimes and the amount of insulin needed to account for carbohydrate intake and capture a photograph of their food. Glucose data could also be integrated to provide an all-inclusive app interface with information about glucose levels, activity, insulin dosage, and meal composition. The results revealed that patients consumed more carbohydrates than they expected and, in the beginning, miscalculated the insulin dosage required to account for carbohydrate intake. Patients found the app supportive for diabetes management, feeling that observing their food made them more mindful of their eating habits and helped them calculate carbohydrates more accurately [19]. A previous study using the app found that participants thought the pictures, physical activity information, integration of pre- and postprandial glucose measurements, and insulin dosages helped 
them develop a better understanding of how those factors impact glucose measurements [251].

Text message- and phone call-based systems have also been used to collect EMA [252,267-269]. For example, Warnick et al [269] recently tested the accuracy of self-reported SMBG and identified in-the-moment factors that create barriers and motivation for SMBG checks via text surveys. They found that only $39.6 \%$ of self-reported SMBG values were accurate, with health being a motivator for SMBG checks, whereas forgetting, not having their devices, and ignoring diabetes tasks were reported as barriers [269]. Furthermore, phone call-based systems have been developed to determine what real-life dietary factors (eg, carbohydrate intake, fiber intake, and physical activity) impact glucose fluctuations and diabetes self-care behaviors (eg, SMBG checks and insulin administration) [270,271]. For example, Mulvaney et al [271] used an automated, interactive touch-tone telephone response system to determine the environmental factors influencing SMBG checks and insulin administration. Overall, participants reported missing more glucose checks in the morning (59.4\%) than in the afternoon $(27.5 \%)$ or evening $(13.2 \%)$. Participants also reported missing more insulin doses in the morning (74.1\%) than in the afternoon (17.9\%) or evening (8.0\%) [271], suggesting that mornings may be particularly challenging for youth with T1D. This information, which may otherwise have been missed if collected in a laboratory setting, could potentially provide a unique target for more tailored interventions addressing challenges with morning routines.

\section{Using Smartphone Apps and Phone-Based Systems to Improve T1D}

The apps and phone-based programs often include educational components (eg, teaching T1D-related information, promoting problem-solving skills, reminders to participate in diabetes care behaviors, positive psychology interventions, and cognitive behavioral treatments) with the goal of improving T1D self-care and glycemic control [272-284]. These app and phone-based mHealth programs have been shown to be related to improved glycemic control (eg, lower $\mathrm{HbA}_{1 \mathrm{c}}$, mean blood glucose, mean fasting glucose, and postprandial glucose levels), increased frequency of SMBG testing, reduced frequency of hypoglycemia, improved quality of life, decreased disengagement coping, reduced parental intrusions in diabetes care for youth who checked glucose regularly, reduced urgent diabetes-related calls by school nurses, decreased hospitalizations, reduced emergency department visits, increased feelings of safety, increased confidence, decreased worry over hypoglycemia, and increased T1D self-care compliance [13,254,255,257,258,262,263,272,273,276-278,280,285,286]. For example, the SuperEgo system was designed to provide patients with individually tailored texts on topics such as stigma, burnout, stress, and sports and exercise with regard to T1D. They found that the intervention group maintained their $\mathrm{HbA}_{1 \mathrm{c}}$ level, whereas the control group had an increased $\mathrm{HbA}_{1 \mathrm{c}}$ level [272]. These tools can also be integrative such that participants receive momentary feedback about their T1D treatment based on the information they log in the app or phone system. For example, Bin-Abbas et al [276] found that youth in an intervention where patients sent glucose readings to their T1D management team and received feedback (eg, how to adjust insulin dosage to avoid dysglycemia) had improved T1D control.

Importantly, these studies have revealed that certain patient characteristics may make a child with T1D more likely to respond to phone-based systems. For example, Herbert et al [268] found that girls and patients who said they sent a large amount of personal texts in their daily lives were more likely to respond to a text message-based intervention. Furthermore, Bergner et al [275] found that youths with T1D found a text-based system for a positive psychology intervention more acceptable than phone call-based systems. However, although some studies have found that app- and phone-based program usage can improve T1D not all found statistically significant differences [282,287], and some found increased patient burden. For example, studies have shown increased conflict in families with app usage, including an increased perception of conflict about logging blood sugars, a sense of increased nagging from parents if the youths checked their glucose irregularly, decreased caring behaviors from parents, and increased unsupportive behaviors from parents [263,281].

Social app platforms have also been considered for better understanding and treating T1D in youths in their daily lives. For example, a study found that participants wanted to incorporate a social platform in a diabetes decision tool app [288], whereas another study used the Instagram social platform as a tool to collect data about what T1D looks like in daily life [289]. However, it is important to note that youth with T1D could also potentially feel pressured or discouraged by social media if they observe others posting about perfect blood glucose levels if they do not obtain similar readings. This is concerning as research has shown a relationship between comparison in social media and poor mental health [290]. Furthermore, there can be misleading information on social media about diabetes and health [291], which could potentially be harmful to self-care in youth.

\section{Limitations of Smartphone Apps and Phone-Based Systems}

The limitations associated with smartphone apps and phone-based systems are similar to those described for PDA. However, there are additional limitations. If a study uses a bring-your-own-device protocol, there may still be a sizable number of participants who do not own a device, resulting in selection bias if only individuals in higher economic groups have access to their own device. A bring-your-own-device platform might also require the development of different smartphone app versions (eg, iOS and Android) as participants may have a variety of phone types (eg, iPhone vs Android) that may not be compatible with the same app version. Finally, there may be concerns about damage to a participant's own device or a study-provided device, such as cracked screens, that may interfere with data collection. On the other hand, if the study needs to provide a device for all participants, there could be study cost challenges. 


\section{Smartphone Apps and Phone-Based Systems Conclusions}

Overall, smartphone apps and phone-based systems can provide a platform for collecting information that helps paint a more detailed picture of the daily experiences and challenges youth with T1D face that may not be otherwise captured reliably if assessed retrospectively in a laboratory or clinical setting. Thus far, numerous psychosocial and contextual factors have been found to be associated with T1D self-care behavior, such as fatigue, time of day, inaccessible devices, forgetfulness, and ignoring diabetes tasks. Taken together, this knowledge could potentially promote more defined interventional targets for improved glycemic control in youth with T1D (eg, developing different morning routines to promote self-care) that could potentially be delivered via an mHealth platform.

\section{Discussion}

\section{Principal Findings}

Overall, EMA has been used to better understand T1D in the daily lives of youth. EMA collection methods can provide significant advantages over in-lab testing, which may be confounded by phenomena such as recall bias and changes in behavior that result from the mere fact of being observed (eg, white-coat phenomenon) [12,202]. These methods also have the benefit of producing a much richer data set to better describe patterns of physiological and behavioral responses in T1D versus one-time snapshots.

EMA tools have already provided important information on care behaviors, physiological fluctuations, and complications of T1D that youth can experience in everyday life. CGMs have provided a great deal of information on glucose patterns, actigraphy has highlighted daily sleep challenges, and ABPM has shown the prominence of abnormalities in blood pressure and heart function in young people with T1D that can lead to other complications such as kidney disease. PDAs, smartphone apps, and phone-based systems have also uncovered numerous psychosocial and contextual environmental factors associated with T1D self-care (eg, wanting to fit into a group or time of day) and the negative consequences of glucose outside the recommended range (eg, cognitive impairment) [18,246,250]. Preliminary studies have also shown that smartphone apps and phone-based systems provide a potential platform for mHealth interventions for T1D and other conditions, such as impaired sleep [197,198].

Given the significant benefits of EMA, there is a great need for its expansion to study T1D-related factors in the daily lives of youth. Larger and more diverse study samples are of the utmost importance. Including individuals with newly diagnosed T1D could provide the opportunity for clinicians to intervene with behaviors that can lead to medical complications early before they are established versus trying to eliminate them later in the course of the disease. EMA methods may also provide an opportunity to reach populations currently underrepresented in research, such as those with lower socioeconomic status, racial or ethnic minority status, or those living in rural areas that may have less access to clinics and research facilities [292,293]. This is especially important because some of these populations have consistently been shown to have worse T1D-related outcomes [294]. Furthermore, EMA methods are less dependent on physical laboratory space, which may be an advantage in circumstances when there are barriers to access, such as during the COVID-19 pandemic or for patients who have barriers to travel to the laboratory.

Future research should also expand the use of combined EMA method systems. An area in which this combination could be particularly helpful is measuring the relationship between glucose patterns and T1D complications in daily life, such as cognitive impairment (eg, glucose measured via CGM or cognitive function measured via testing on a smartphone app). Given that acute T1D complications and chronic hyperglycemia have been associated with acute and long-lasting cognitive differences when measured in the laboratory [11] and the relationship between SMBG and cognitive impairment in Gonder-Fredrick's EMA study [246], it is essential to better understand the relationship between daily glucose patterns measured via CGM and cognitive function in the real world, especially considering that youths spend about $25 \%$ of their time participating in school activities during the academic year [295,296], which requires substantial, ongoing cognitive effort using cognitive functions that can fluctuate throughout the day [297-301].

There may also be other fluctuating short-term complications associated with daily glycemic changes to be explored, such as vision. In-lab research has shown that short-term fluctuations in glucose can significantly alter nerve function and morphology in the eye [302]. Given that youths can have significant glucose variability [7], it is possible that they may experience daily vision changes. Research studies using EMA methods could be conducted to determine how frequently patients experience vision changes throughout the day and whether regular disruptions predict long-term complications such as retinopathy.

Furthermore, psychiatric conditions are more common in individuals with T1D than in those without T1D [303]. EMA methods can be used to gain better insight into the patterns of psychiatric symptoms in daily life. For example, one could collect repeated information about anxiety to determine whether its origin is T1D related, given that symptoms of glucose variability and feelings of anxiety can overlap (eg, shakiness and sweatiness because of hypoglycemia or because of nerves over a school exam). The timing of symptoms could also be evaluated to determine if there is a relationship between these symptoms and glucose fluctuations (eg, anxiety is higher with frequent swings in glucose). This information could potentially be used to aid therapists and medical care teams in tailoring behavioral interventions to help ameliorate symptoms when they are most severe.

More sophisticated analytical systems could also be used to better integrate data from different EMA modalities (eg, machine learning) for a more fully developed model of factors that predict T1D self-care behaviors or disease complications. The rapid development of new T1D care systems, such as the closed-loop system, makes this a unique time to conduct such combination EMA studies. EMA data collection could also be combined 
with mHealth interventional platforms to make treatment adjustments in real time, as youths appear to enjoy technology platforms. Furthermore, these technology-based interventions may provide motivation, self-efficacy, and adherence benefits [304]. The implementation of mHealth interventions while simultaneously collecting in-the-moment data could potentially help individualize treatment by providing a type of precision-based medicine.

\section{General Conclusions}

In conclusion, as shown in the textboxes (Textboxes 1 and 2), EMA methods such as CGM, actigraphy, ABPM, PDAs, smartphone apps, and phone-based systems have unique strengths that can help the field better understand T1D in the daily lives of youth. Such an understanding could potentially lead to tailored interventions to improve quality of life and reduce the risk of short- and long-term complications of T1D. However, the field is still in its infancy and should be expanded in future research to address the limitations of each tool.

Textbox 1. Strengths of popular technological ecological momentary assessment tools to measure type 1 diabetes in the daily lives of youth, including continuous glucose monitoring, actigraphy, ambulatory blood pressure monitoring, personal digital assistants, and phone app, call, and text-based systems.

Continuous glucose monitoring

- Increased amount of glucose data

- More comprehensive glucose patterns

- Improved diabetes management and outcomes

- Provides a sense of empowerment for youth

Actigraphy

- Inexpensive

- Noninvasive

- $\quad$ Objective; more valid than self-report

- More comprehensive view of sleep patterns

- $\quad$ Records numerous measures of sleep

- Captures sleep in the natural environment

Ambulatory blood pressure monitoring

- $\quad$ Provides large amounts of data

- Measures heart function across daily contexts

- Avoids confounding in-lab factors (eg, white-coat phenomenon)

Personal digital assistant

- Captures complex relationships between diabetes-related variables in real life

- Connects to the internet for data upload

- Organizes information

App, call, text

- Captures complex relationships between diabetes-related variables in real life

- Typically with a participant in real time

- Potential platform for treatment intervention 
Textbox 2. Limitations of popular technological ecological momentary assessment tools to measure type 1 diabetes in the daily lives of youth, including continuous glucose monitoring, actigraphy, ambulatory blood pressure monitoring, personal digital assistants, and phone app, call, and text-based systems.

Continuous glucose monitoring

- Expense and insurance difficulties

- Sensor discomfort

- $\quad$ Alarm fatigue

- $\quad$ Psychological toil (eg, anxiety)

- $\quad$ Measurement errors

Actigraphy

- Low specificity

- Imperfect measure of atypical sleep

- Not always comparable with polysomnography

- $\quad$ Variable device use across studies

Ambulatory blood pressure monitoring

- Potential obstacle in daily life

- Inaccurate readings

Personal digital assistant

- Validity concerns

- Testing compliance difficulties

App, call, and text

- Validity concerns

- $\quad$ Expensive equipment

- Hardware and software issues

- $\quad$ Bring your own device can lead to selection bias (eg, only recruiting those able to afford devices)

- Bring your own device can lead to data collection difficulties (eg, cracked screens)

- $\quad$ Testing compliance difficulties

\section{Acknowledgments}

The authors would like to thank the funding sources that supported work on this viewpoint including the Washington University in St. Louis (WUSTL) Biomedical Research Training in Drug Abuse training grant (T32DA007261), WUSTL Transdisciplinary Postdoctoral Training Program in Obesity and Cardiovascular Disease (T32HL130357), WUSTL undergraduate Enhancing Neuroscience Diversity through Undergraduate Research Education Experiences (ENDURE) training program (2R25NS090985), and WUSTL and BJC Healthcare Innovation Lab Big Ideas grant.

\section{Authors' Contributions}

MKR wrote the first draft of this manuscript. All authors (MKR, AM, MRS, JN, and TH) developed the review design, critically reviewed the manuscript, and edited the manuscript.

\section{Conflicts of Interest}

MRS has family reporting stock in Pfizer. Other authors declared no conflict of interest.

\section{References}

1. Allen PJ, Vessey JA. Primary Care of Child With Chronic Condition 4th Edition. Maryland Heights, Missouri: CV Mosby Co; 2004. 
2. Mayer-Davis EJ, Lawrence JM, Dabelea D, Divers J, Isom S, Dolan L, SEARCH for Diabetes in Youth Study. Incidence trends of type 1 and type 2 diabetes among youths, 2002-2012. N Engl J Med 2017 Apr 13;376(15):1419-1429 [FREE Full text] [doi: 10.1056/NEJMoa1610187] [Medline: 28402773]

3. Bluestone JA, Herold K, Eisenbarth G. Genetics, pathogenesis and clinical interventions in type 1 diabetes. Nature 2010 Apr 29;464(7293):1293-1300 [FREE Full text] [doi: 10.1038/nature08933] [Medline: 20432533]

4. American Diabetes Association. Good to know: factors affecting blood glucose. Clin Diabetes 2018 Apr;36(2):202 [FREE Full text] [doi: 10.2337/cd18-0012] [Medline: 29686462]

5. Carroll MF, Schade DS. The dawn phenomenon revisited: implications for diabetes therapy. Endocr Pract 2005; 11(1):55-64. [doi: 10.4158/EP.11.1.55] [Medline: 16033737 ]

6. Visekruna S, Hall LM, Parry M, Spalding K. Intersecting health policy and the social determinants of health in pediatric type 1 diabetes management and care. J Pediatr Nurs 2017;37:62-69. [doi: 10.1016/j.pedn.2017.06.001] [Medline: 28683888]

7. Tansey M, Beck R, Ruedy K, Tamborlane W, Cheng P, Kollman C, Diabetes Research in Children Network (DirecNet). Persistently high glucose levels in young children with type 1 diabetes. Pediatr Diabetes 2016 Mar;17(2):93-100 [FREE Full text] [doi: 10.1111/pedi.12248] [Medline: 25496062]

8. Cryer PE. Hypoglycemia in type 1 diabetes mellitus. Endocrinol Metab Clin North Am 2010 Sep;39(3):641-654 [FREE Full text] [doi: 10.1016/j.ecl.2010.05.003] [Medline: 20723825]

9. Atkinson MA, Eisenbarth GS, Michels AW. Type 1 diabetes. Lancet 2014 Jan 04;383(9911):69-82 [FREE Full text] [doi: 10.1016/S0140-6736(13)60591-7] [Medline: 23890997]

10. Perez KM, Hamburger ER, Lyttle M, Williams R, Bergner E, Kahanda S, et al. Sleep in type 1 diabetes: implications for glycemic control and diabetes management. Curr Diab Rep 2018 Feb 05;18(2):5 [FREE Full text] [doi: 10.1007/s11892-018-0974-8] [Medline: 29399719]

11. Cato A, Hershey T. Cognition and type 1 diabetes in children and adolescents. Diabetes Spectr 2016 Nov;29(4):197-202. [doi: 10.2337/ds16-0036] [Medline: 27899870]

12. Shiffman S, Stone AA, Hufford MR. Ecological momentary assessment. Annu Rev Clin Psychol 2008;4:1-32. [doi: 10.1146/annurev.clinpsy.3.022806.091415] [Medline: 18509902]

13. Goyal S, Nunn CA, Rotondi M, Couperthwaite AB, Reiser S, Simone A, et al. A mobile app for the self-management of type 1 diabetes among adolescents: a randomized controlled trial. JMIR Mhealth Uhealth 2017 Jun 19;5(6):e82 [FREE Full text] [doi: 10.2196/mhealth.7336] [Medline: 28630037]

14. Rideout V, Robb MB. The common sense census: media use by tweens and teens. 2019. URL: https://www. commonsensemedia.org/sites/default/files/uploads/research/2019-census-8-to-18-key-findings-updated.pdf [accessed 2021-04-15]

15. Evenson KR, Goto MM, Furberg RD. Systematic review of the validity and reliability of consumer-wearable activity trackers. Int J Behav Nutr Phys Act 2015 Dec 18;12:159 [FREE Full text] [doi: 10.1186/s12966-015-0314-1] [Medline: 26684758]

16. Johnson KT, Picard RW. Advancing neuroscience through wearable devices. Neuron 2020 Oct 14;108(1):8-12. [doi: 10.1016/j.neuron.2020.09.030] [Medline: 33058768]

17. Miller KM, Beck RW, Foster NC, Maahs DM. HbA1c levels in type 1 diabetes from early childhood to older adults: a deeper dive into the influence of technology and socioeconomic status on HbA1c in the T1D exchange clinic registry findings. Diabetes Technol Ther 2020 Sep;22(9):645-650. [doi: 10.1089/dia.2019.0393] [Medline: $\underline{31905008]}$

18. Helgeson VS, Lopez LC, Kamarck T. Peer relationships and diabetes: retrospective and ecological momentary assessment approaches. Health Psychol 2009 May;28(3):273-282 [FREE Full text] [doi: 10.1037/a0013784] [Medline: 19450032]

19. Frøisland DH, Årsand E. Integrating visual dietary documentation in mobile-phone-based self-management application for adolescents with type 1 diabetes. J Diabetes Sci Technol 2015 May;9(3):541-548 [FREE Full text] [doi: 10.1177/1932296815576956] [Medline: 25901020]

20. Battelino T, Danne T, Bergenstal RM, Amiel SA, Beck R, Biester T, et al. Clinical targets for continuous glucose monitoring data interpretation: recommendations from the international consensus on time in range. Diabetes Care 2019 Aug;42(8):1593-1603 [FREE Full text] [doi: 10.2337/dci19-0028] [Medline: 31177185]

21. Ceriello A, Monnier L, Owens D. Glycaemic variability in diabetes: clinical and therapeutic implications. Lancet Diabetes Endocrinol 2019 Mar;7(3):221-230. [doi: 10.1016/s2213-8587(18)30136-0]

22. Cappon G, Vettoretti M, Sparacino G, Facchinetti A. Continuous glucose monitoring sensors for diabetes management: a review of technologies and applications. Diabetes Metab J 2019 Aug;43(4):383-397 [FREE Full text] [doi: 10.4093/dmj.2019.0121] [Medline: 31441246]

23. Rewers M, Pihoker C, Donaghue K, Hanas R, Swift P, Klingensmith GJ. Assessment and monitoring of glycemic control in children and adolescents with diabetes. Pediatr Diabetes 2009 Sep;10 Suppl 12:71-81. [doi: 10.1111/j.1399-5448.2009.00582.x] [Medline: 19754620]

24. Patton SR, Clements MA. Continuous glucose monitoring versus self-monitoring of blood glucose in children with type 1 diabetes- are there pros and cons for both? US Endocrinol 2012;8(1):27-29 [FREE Full text] [Medline: 24312136]

25. American Diabetes Association. 7. Diabetes technology: standards of medical care in diabetes-2019. Diabetes Care 2019 Jan;42(Suppl 1):71-80. [doi: 10.2337/dc19-S007] [Medline: 30559233] 
26. Fiallo-Scharer R, Diabetes Research in Children Network Study Group. Eight-point glucose testing versus the continuous glucose monitoring system in evaluation of glycemic control in type 1 diabetes. J Clin Endocrinol Metab 2005 Jun;90(6):3387-3391. [doi: 10.1210/jc.2004-2510] [Medline: $\underline{\text { 15784705] }}$

27. Hathout E, Patel N, Southern C, Hill J, Anderson R, Sharkey J, et al. Home use of the GlucoWatch G2 biographer in children with diabetes. Pediatrics 2005 Mar;115(3):662-666. [doi: 10.1542/peds.2004-0820] [Medline: 15741369]

28. Carchidi C, Holland C, Minnock P, Boyle D. New technologies in pediatric diabetes care. MCN Am J Matern Child Nurs 2011;36(1):32-9;-quiz 40-1. [doi: 10.1097/nmc.0b013e3181fb8c3a] [Medline: 21204305]

29. Ahmet A, Dagenais S, Barrowman NJ, Collins CJ, Lawson ML. Prevalence of nocturnal hypoglycemia in pediatric type 1 diabetes: a pilot study using continuous glucose monitoring. J Pediatr 2011 Aug;159(2):297-302. [doi: 10.1016/j.jpeds.2011.01.064] [Medline: 21414634]

30. Lawton J, Blackburn M, Allen J, Campbell F, Elleri D, Leelarathna L, et al. Patients' and caregivers' experiences of using continuous glucose monitoring to support diabetes self-management: qualitative study. BMC Endocr Disord 2018 Feb 20;18(1):12 [FREE Full text] [doi: 10.1186/s12902-018-0239-1] [Medline: 29458348]

31. Foster NC, Beck RW, Miller KM, Clements MA, Rickels MR, DiMeglio LA, et al. State of type 1 diabetes management and outcomes from the T1D exchange in 2016-2018. Diabetes Technol Ther 2019 Feb;21(2):66-72 [FREE Full text] [doi: 10.1089/dia.2018.0384] [Medline: 30657336]

32. van den Boom L, Karges B, Auzanneau M, Rami-Merhar B, Lilienthal E, von Sengbusch S, et al. Temporal trends and contemporary use of insulin pump therapy and glucose monitoring among children, adolescents, and adults with type 1 diabetes between 1995 and 2017. Diabetes Care 2019 Nov;42(11):2050-2056. [doi: 10.2337/dc19-0345] [Medline: 31488568]

33. Miller KM, Hermann J, Foster N, Hofer SE, Rickels MR, Danne T, T1D Exchange and DPV Registries. Longitudinal changes in continuous glucose monitoring use among individuals with type 1 diabetes: international comparison in the German and Austrian DPV and U.S. T1D exchange registries. Diabetes Care 2020 Jan;43(1):e1-e2 [FREE Full text] [doi: 10.2337/dc19-1214] [Medline: $\underline{31672703}$ ]

34. Nansel TR, Gellar L, McGill A. Effect of varying glycemic index meals on blood glucose control assessed with continuous glucose monitoring in youth with type 1 diabetes on basal-bolus insulin regimens. Diabetes Care 2008 Apr;31(4):695-697 [FREE Full text] [doi: $\underline{10.2337 / \mathrm{dc} 07-1879]}$ [Medline: $\underline{18202243}$ ]

35. Kaplan W, Afandi B, Al Hassani N, Hadi S, Zoubeidi T. Comparison of continuous glucose monitoring in adolescents with type 1 diabetes: Ramadan versus non-Ramadan. Diabetes Res Clin Pract 2017 Dec;134:178-182. [doi:

10.1016/j.diabres.2017.10.010] [Medline: 29061323]

36. Afandi B, Kaplan W, Al Hassani N, Hadi S, Mohamed A. Correlation between pre-ramadan glycemic control and subsequent glucose fluctuation during fasting in adolescents with type 1 diabetes. J Endocrinol Invest 2017 Jul;40(7):741-744. [doi: 10.1007/s40618-017-0633-y] [Medline: 28239763]

37. Peairs AD, Shah AS, Summer S, Hess M, Couch SC. Effects of the dietary approaches to stop hypertension (DASH) diet on glucose variability in youth with type 1 diabetes. Diabetes Manag (Lond) 2017;7(5):383-391 [FREE Full text] [Medline: 29333199]

38. Zhong VW, Crandell JL, Shay CM, Gordon-Larsen P, Cole SR, Juhaeri J, et al. Dietary intake and risk of non-severe hypoglycemia in adolescents with type 1 diabetes. J Diabetes Complications 2017 Aug;31(8):1340-1347 [FREE Full text] [doi: 10.1016/j.jdiacomp.2017.04.017] [Medline: 28476567]

39. Nansel TR, Lipsky LM, Liu A. Greater diet quality is associated with more optimal glycemic control in a longitudinal study of youth with type 1 diabetes. Am J Clin Nutr 2016 Jul;104(1):81-87 [FREE Full text] [doi: 10.3945/ajcn.115.126136] [Medline: 27194309]

40. Schiel R, Thomas A, Kaps A, Bieber G. An innovative telemedical support system to measure physical activity in children and adolescents with type 1 diabetes mellitus. Exp Clin Endocrinol Diabetes 2011 Oct;119(9):565-568. [doi: 10.1055/s-0031-1273747] [Medline: 21472657]

41. Singhvi A, Tansey MJ, Janz K, Zimmerman MB, Tsalikian E. Aerobic fitness and glycemic variability in adolescents with type 1 diabetes. Endocr Pract 2014 Jun;20(6):566-570. [doi: 10.4158/EP13211.OR] [Medline: 24449660]

42. Metcalf KM, Singhvi A, Tsalikian E, Tansey MJ, Zimmerman MB, Esliger DW, et al. Effects of moderate-to-vigorous intensity physical activity on overnight and next-day hypoglycemia in active adolescents with type 1 diabetes. Diabetes Care 2014;37(5):1272-1278 [FREE Full text] [doi: 10.2337/dc13-1973] [Medline: 24574352]

43. Moniotte S, Owen M, Barrea T, Robert A, Lysy PA. Outcomes of algorithm-based modifications of insulinotherapy during exercise in MDI vs insulin pump-treated children with type 1 diabetes: results from the TREAD-DIAB study. Pediatr Diabetes 2017 Dec;18(8):925-933. [doi: 10.1111/pedi.12509] [Medline: 28251726]

44. Kordonouri O, Vazeou A, Scharf M, Würsig M, Battelino T, SWEET Group. Striving for control: lessons learned from a successful international type 1 diabetes youth challenge. Acta Diabetol 2017 Apr;54(4):403-409. [doi: 10.1007/s00592-017-0964-3] [Medline: 28154987]

45. Rempel M, Yardley JE, MacIntosh A, Hay JL, Bouchard D, Cornish S, et al. Vigorous intervals and hypoglycemia in type 1 diabetes: a randomized cross over trial. Sci Rep 2018 Oct 26;8(1):15879 [FREE Full text] [doi:

10.1038/s41598-018-34342-6] [Medline: $\underline{\text { 30367116] }}$ 
46. Lormeau B, Pichat S, Dufaitre L, Chamouine A, Gataa M, Rastami J, et al. Impact of a sports project centered on scuba diving for adolescents with type 1 diabetes mellitus: New guidelines for adolescent recreational diving, a modification of the French regulations. Arch Pediatr 2019 Apr;26(3):161-167. [doi: 10.1016/j.arcped.2018.12.006] [Medline: 30885605]

47. Jaggers JR, King KM, Watson SE, Wintergerst KA. Predicting nocturnal hypoglycemia with measures of physical activity intensity in adolescent athletes with type 1 diabetes. Diabetes Technol Ther 2019 Jul;21(7):406-408. [doi:

10.1089/dia.2019.0048] [Medline: 31265348]

48. DeBoer MD, Cherñavvsky DR, Topchyan K, Kovatchev BP, Francis GL, Breton MD. Heart rate informed artificial pancreas system enhances glycemic control during exercise in adolescents with T1D. Pediatr Diabetes 2017 Nov 13;18(7):540-546. [doi: 10.1111/pedi.12454] [Medline: 27734563]

49. Ortiz-Rubio P, Oladunjoye A, Agus MS, Steil GM. Adjusting Insulin Delivery to Activity (AIDA) clinical trial: effects of activity-based insulin profiles on glucose control in children with type 1 diabetes. Pediatr Diabetes 2018 Dec;19(8):1451-1458. [doi: 10.1111/pedi.12752] [Medline: 30120825]

50. Rebesco DB, França SN, Lima VA, Leite N, Smouter L, Souza WC, et al. Different amounts of moderate to vigorous physical activity and change in glycemic variability in adolescents with type 1 diabetes: is there dose-response relationship? Arch Endocrinol Metab 2020;64(3):312-318. [doi: 10.20945/2359-3997000000254] [Medline: 32555999]

51. Perfect MM, Patel PG, Scott RE, Wheeler MD, Patel C, Griffin K, et al. Sleep, glucose, and daytime functioning in youth with type 1 diabetes. Sleep 2012 Jan 01;35(1):81-88 [FREE Full text] [doi: 10.5665/sleep.1590] [Medline: 22215921]

52. Sinisterra M, Hamburger S, Tully C, Hamburger E, Jaser S, Streisand R. Young children with type 1 diabetes: sleep, health-related quality of life, and continuous glucose monitor use. Diabetes Technol Ther 2020 Aug;22(8):639-642. [doi: 10.1089/dia.2019.0437] [Medline: 32027177]

53. Macaulay GC, Galland BC, Boucher SE, Wiltshire EJ, Haszard JJ, Campbell AJ, et al. Impact of type 1 diabetes mellitus, glucose levels, and glycemic control on sleep in children and adolescents: a case-control study. Sleep 2020 Feb 13;43(2):zsz226. [doi: 10.1093/sleep/zsz226] [Medline: 31583407]

54. Schiaffini R, Barbetti F, Rapini N, Inzaghi E, Deodati A, Patera IP, et al. School and pre-school children with type 1 diabetes during Covid-19 quarantine: the synergic effect of parental care and technology. Diabetes Res Clin Pract 2020 Aug;166:108302 [FREE Full text] [doi: 10.1016/j.diabres.2020.108302] [Medline: 32623034]

55. McDonnell CM, Northam EA, Donath SM, Werther GA, Cameron FJ. Hyperglycemia and externalizing behavior in children with type 1 diabetes. Diabetes Care 2007 Sep;30(9):2211-2215. [doi: 10.2337/dc07-0328] [Medline: 17563334]

56. Tanenberg RJ, Welsh JB. Patient behaviors associated with optimum glycemic outcomes with sensor-augmented pump therapy: insights from the STAR 3 study. Endocr Pract 2015 Jan;21(1):41-45. [doi: 10.4158/EP14187.OR] [Medline: 25100386]

57. Wilson DM, Buckingham BA, Kunselman EL, Sullivan MM, Paguntalan HU, Gitelman SE. A two-center randomized controlled feasibility trial of insulin pump therapy in young children with diabetes. Diabetes Care 2005 Jan;28(1):15-19. [doi: 10.2337/diacare.28.1.15] [Medline: 15616227]

58. Deiss D, Kordonouri O, Hartmann R, Hopfenmüller W, Lüpke K, Danne T. Treatment with insulin glargine reduces asymptomatic hypoglycemia detected by continuous subcutaneous glucose monitoring in children and adolescents with type 1 diabetes. Pediatr Diabetes 2007 Jun;8(3):157-162. [doi: 10.1111/j.1399-5448.2007.00252.x] [Medline: 17550426]

59. Danne T, Philotheou A, Goldman D, Guo X, Ping L, Cali A, et al. A randomized trial comparing the rate of hypoglycemia-assessed using continuous glucose monitoring--in 125 preschool children with type 1 diabetes treated with insulin glargine or NPH insulin (the PRESCHOOL study). Pediatr Diabetes 2013 Dec;14(8):593-601 [FREE Full text] [doi: 10.1111/pedi.12051] [Medline: 23730996]

60. Russell SJ, El-Khatib FH, Sinha M, Magyar KL, McKeon K, Goergen LG, et al. Outpatient glycemic control with a bionic pancreas in type 1 diabetes. N Engl J Med 2014 Jul 24;371(4):313-325 [FREE Full text] [doi: 10.1056/NEJMoa1314474] [Medline: 24931572]

61. Chen XY, Dong Q, Li G. Effect of combined application insulin and insulin detemir on continous glucose monitor in children with type 1 diabetes mellitus. Int J Clin Exp Med 2015;8(3):4287-4291 [FREE Full text] [Medline: 26064343]

62. Manousaki D, Deladoëy J, Geoffroy L, Olivier P. Continuous subcutaneous insulin infusion in children: a pilot study validating a protocol to avoid hypoglycemia at initiation. Front Endocrinol (Lausanne) 2017;8:84 [FREE Full text] [doi: 10.3389/fendo.2017.00084] [Medline: 28484424]

63. Wang Y, Gong C, Cao B, Meng X, Wei L, Wu D, et al. Influence of initial insulin dosage on blood glucose dynamics of children and adolescents with newly diagnosed type 1 diabetes mellitus. Pediatr Diabetes 2017 May;18(3):196-203. [doi: 10.1111/pedi.12374] [Medline: 26947770]

64. Bergenstal RM, Tamborlane WV, Ahmann A, Buse JB, Dailey G, Davis SN, STAR 3 Study Group. Effectiveness of sensor-augmented insulin-pump therapy in type 1 diabetes. N Engl J Med 2010 Jul 22;363(4):311-320. [doi: 10.1056/NEJMoa1002853] [Medline: 20587585]

65. Slover RH, Welsh JB, Criego A, Weinzimer SA, Willi SM, Wood MA, et al. Effectiveness of sensor-augmented pump therapy in children and adolescents with type 1 diabetes in the STAR 3 study. Pediatr Diabetes 2012 Feb;13(1):6-11. [doi: 10.1111/j.1399-5448.2011.00793.x] [Medline: 21722284] 
66. Breton M, Farret A, Bruttomesso D, Anderson S, Magni L, Patek S, International Artificial Pancreas Study Group. Fully integrated artificial pancreas in type 1 diabetes: modular closed-loop glucose control maintains near normoglycemia. Diabetes 2012 Sep;61(9):2230-2237 [FREE Full text] [doi: 10.2337/db11-1445] [Medline: $\underline{22688340}$ ]

67. Buckingham BA, Raghinaru D, Cameron F, Bequette BW, Chase HP, Maahs DM, In Home Closed Loop Study Group. Predictive low-glucose insulin suspension reduces duration of nocturnal hypoglycemia in children without increasing ketosis. Diabetes Care 2015 Jul;38(7):1197-1204 [FREE Full text] [doi: 10.2337/dc14-3053] [Medline: 26049549]

68. Ly TT, Keenan DB, Roy A, Han J, Grosman B, Cantwell M, et al. Automated overnight closed-loop control using a proportional-integral-derivative algorithm with insulin feedback in children and adolescents with type 1 diabetes at diabetes camp. Diabetes Technol Ther 2016 Jun;18(6):377-384. [doi: 10.1089/dia.2015.0431] [Medline: 27183197]

69. Elbarbary NS. Effectiveness of the low-glucose suspend feature of insulin pump during fasting during Ramadan in type 1 diabetes mellitus. Diabetes Metab Res Rev 2016 Sep;32(6):623-633. [doi: 10.1002/dmrr.2781] [Medline: 26789012]

70. Calhoun PM, Buckingham BA, Maahs DM, Hramiak I, Wilson DM, Aye T, In Home Closed Loop Study Group. Efficacy of an overnight predictive low-glucose suspend system in relation to hypoglycemia risk factors in youth and adults with type 1 diabetes. J Diabetes Sci Technol 2016 Nov;10(6):1216-1221 [FREE Full text] [doi: 10.1177/1932296816645119] [Medline: 27207890]

71. Sharifi A, De Bock MI, Jayawardene D, Loh MM, Horsburgh JC, Berthold CL, et al. Glycemia, treatment satisfaction, cognition, and sleep quality in adults and adolescents with type 1 diabetes when using a closed-loop system overnight versus sensor-augmented pump with low-glucose suspend function: a randomized crossover study. Diabetes Technol Ther 2016 Dec;18(12):772-783. [doi: 10.1089/dia.2016.0288] [Medline: 27835037]

72. Favero SD, Boscari F, Messori M, Rabbone I, Bonfanti R, Sabbion A, et al. Randomized summer camp crossover trial in 5- to 9-year-old children: outpatient wearable artificial pancreas is feasible and safe. Diabetes Care 2016 Jul;39(7):1180-1185. [doi: 10.2337/dc15-2815] [Medline: 27208335]

73. Petruzelkova L, Pickova K, Sumnik Z, Soupal J, Obermannova B. Effectiveness of smartguard technology in the prevention of nocturnal hypoglycemia after prolonged physical activity. Diabetes Technol Ther 2017 May;19(5):299-304. [doi: 10.1089/dia.2016.0459] [Medline: 28520532]

74. Forlenza GP, Raghinaru D, Cameron F, Bequette BW, Chase HP, Wadwa RP, In-Home Closed-Loop (IHCL) Study Group. Predictive hyperglycemia and hypoglycemia minimization: in-home double-blind randomized controlled evaluation in children and young adolescents. Pediatr Diabetes 2018 May;19(3):420-428 [FREE Full text] [doi: 10.1111/pedi.12603] [Medline: 29159870]

75. Renard E, Tubiana-Rufi N, Bonnemaison-Gilbert E, Coutant R, Dalla-Vale F, Farret A, et al. Closed-loop driven by control-to-range algorithm outperforms threshold-low-glucose-suspend insulin delivery on glucose control albeit not on nocturnal hypoglycaemia in prepubertal patients with type 1 diabetes in a supervised hotel setting. Diabetes Obes Metab 2019 Jan;21(1):183-187. [doi: 10.1111/dom.13482] [Medline: $\underline{30047223}$ ]

76. Biester T, Nir J, Remus K, Farfel A, Muller I, Biester S, et al. DREAM5: an open-label, randomized, cross-over study to evaluate the safety and efficacy of day and night closed-loop control by comparing the MD-Logic automated insulin delivery system to sensor augmented pump therapy in patients with type 1 diabetes at home. Diabetes Obes Metab 2018 Nov 26:822-828. [doi: 10.1111/dom.13585] [Medline: 30478937]

77. Cherubini V, Gesuita R, Skrami E, Rabbone I, Bonfanti R, Arnaldi C, et al. Optimal predictive low glucose management settings during physical exercise in adolescents with type 1 diabetes. Pediatr Diabetes 2019 Feb;20(1):107-112. [doi: 10.1111/pedi.12792] [Medline: 30378759]

78. Buckingham B, Beck RW, Ruedy KJ, Cheng P, Kollman C, Weinzimer SA, Diabetes Research in Children Network (DirecNet) Study Group, Type 1 Diabetes TrialNet Study Group. Effectiveness of early intensive therapy on $\beta$-cell preservation in type 1 diabetes. Diabetes Care 2013 Dec;36(12):4030-4035 [FREE Full text] [doi: 10.2337/dc13-1074] [Medline: 24130350]

79. Chan CL, Taki I, Dong F, Hoffman M, Norris JM, Klingensmith G, et al. Comparison of metabolic outcomes in children diagnosed with type 1 diabetes through research screening (diabetes autoimmunity study in the young [daisy]) versus in the community. Diabetes Technol Ther 2015 Sep;17(9):649-656 [FREE Full text] [doi: 10.1089/dia.2015.0029] [Medline: $\underline{26317880]}$

80. Russell SJ, Hillard MA, Balliro C, Magyar KL, Selagamsetty R, Sinha M, et al. Day and night glycaemic control with a bionic pancreas versus conventional insulin pump therapy in preadolescent children with type 1 diabetes: a randomised crossover trial. Lancet Diabetes Endocrinol 2016 Mar;4(3):233-243. [doi: 10.1016/S2213-8587(15)00489-1] [Medline: 26850709]

81. Anderson D, Phelan H, Jones K, Smart C, Oldmeadow C, King B, et al. Evaluation of a novel continuous glucose monitoring guided system for adjustment of insulin dosing - PumpTune: a randomized controlled trial. Pediatr Diabetes 2016 Nov;17(7):478-482. [doi: 10.1111/pedi.12332] [Medline: 26701831]

82. Picard S, Hanaire H, Baillot-Rudoni S, Gilbert-Bonnemaison E, Not D, Reznik Y, et al. Evaluation of the adherence to continuous glucose monitoring in the management of type 1 diabetes patients on sensor-augmented pump therapy: the SENLOCOR study. Diabetes Technol Ther 2016 Mar;18(3):127-135. [doi: 10.1089/dia.2015.0240] [Medline: 26950530] 
83. Biester T, Kordonouri O, Holder M, Remus K, Kieninger-Baum D, Wadien T, et al. "Let the Algorithm Do the Work": reduction of hypoglycemia using sensor-augmented pump therapy with predictive insulin suspension (SmartGuard) in pediatric type 1 diabetes patients. Diabetes Technol Ther 2017 Mar;19(3):173-182 [FREE Full text] [doi: 10.1089/dia.2016.0349] [Medline: 28099035]

84. Messer LH, Calhoun P, Buckingham B, Wilson DM, Hramiak I, Ly TT, In Home Closed Loop Study Group. In-home nighttime predictive low glucose suspend experience in children and adults with type 1 diabetes. Pediatr Diabetes 2017 Aug;18(5):332-339 [FREE Full text] [doi: 10.1111/pedi.12395] [Medline: 27125223]

85. Huyett LM, Ly TT, Forlenza GP, Reuschel-DiVirgilio S, Messer LH, Wadwa RP, et al. Outpatient closed-loop control with unannounced moderate exercise in adolescents using zone model predictive control. Diabetes Technol Ther 2017 Jun;19(6):331-339. [doi: 10.1089/dia.2016.0399] [Medline: 28459617]

86. DeBoer MD, Breton MD, Wakeman C, Schertz EM, Emory EG, Robic JL, et al. Performance of an artificial pancreas system for young children with type 1 diabetes. Diabetes Technol Ther 2017 May;19(5):293-298. [doi: 10.1089/dia.2016.0424] [Medline: 28426239]

87. Braune K, O'Donnell S, Cleal B, Lewis D, Tappe A, Willaing I, et al. Real-world use of do-it-yourself artificial pancreas systems in children and adolescents with type 1 diabetes: online survey and analysis of self-reported clinical outcomes. JMIR Mhealth Uhealth 2019 Jul 30;7(7):e14087 [FREE Full text] [doi: 10.2196/14087] [Medline: 31364599]

88. Suzuki J, Urakami T, Yoshida K, Kuwabara R, Mine Y, Aoki M, et al. Association between scanning frequency of flash glucose monitoring and continuous glucose monitoring-derived glycemic makers in children and adolescents with type 1 diabetes. Pediatr Int 2021 Feb;63(2):154-159. [doi: 10.1111/ped.14412] [Medline: 32744360]

89. Gaweł WB, Deja G, Kamińska H, Tabor A, Skała-Zamorowska E, Jarosz-Chobot P. How does a predictive low glucose suspend (PLGS) system tackle pediatric lifespan challenges in diabetes treatment? Real world data analysis. Pediatr Diabetes 2020 Mar;21(2):280-287. [doi: 10.1111/pedi.12944] [Medline: 31715059]

90. Beato-Víbora PI, Gallego-Gamero F, Lázaro-Martín L, Romero-Pérez MD, Arroyo-Díez FJ. Prospective analysis of the impact of commercialized hybrid closed-loop system on glycemic control, glycemic variability, and patient-related outcomes in children and adults: a focus on superiority over predictive low-glucose suspend technology. Diabetes Technol Ther 2020 Dec;22(12):912-919. [doi: 10.1089/dia.2019.0400] [Medline: $\underline{31855446]}$

91. Burckhardt MA, Chetty T, Smith GJ, Adolfsson P, de Bock M, Jones TW, et al. Use of continuous glucose monitoring trends to facilitate exercise in children with type 1 diabetes. Diabetes Technol Ther 2019 Jan;21(1):51-55. [doi:

10.1089/dia.2018.0292] [Medline: 30620642]

92. Gonder-Frederick LA, Grabman JH, Shepard JA. Diabetes Alert Dogs (DADs): an assessment of accuracy and implications. Diabetes Res Clin Pract 2017 Dec;134:121-130 [FREE Full text] [doi: 10.1016/j.diabres.2017.09.009] [Medline: 28974470]

93. Demir G, Özen S, Çetin H, Darcan S, Gökşen D. Effect of education on impaired hypoglycemia awareness and glycemic variability in children and adolescents with type 1 diabetes mellitus. J Clin Res Pediatr Endocrinol 2019 May 28;11(2):189-195 [FREE Full text] [doi: 10.4274/jcrpe.galenos.2019.2019.0009] [Medline: 30701953]

94. Bassi M, Minuto N, Fichera G, Rebora C, Parodi A, Natoli V, et al. Practical approach to using trend arrows on real-time continuous glucose monitoring system in type 1 diabetes adolescents living camp setting treated with multiple daily injection or continuous subcutaneous insulin infusion insulin therapy. J Diabetes Sci Technol 2020 Jun 19. [doi: 10.1177/1932296820934803] [Medline: 32552001]

95. Jamiołkowska M, Jamiołkowska I, Łuczyński W, Tołwińska J, Bossowski A, Olszewska BG. Impact of real-time continuous glucose monitoring use on glucose variability and endothelial function in adolescents with type 1 diabetes: new technology-new possibility to decrease cardiovascular risk? J Diabetes Res 2016;2016:4385312 [FREE Full text] [doi: 10.1155/2016/4385312] [Medline: 26649320]

96. Welsh JB, Derdzinski M, Parker AS, Puhr S, Jimenez A, Walker T. Real-time sharing and following of continuous glucose monitoring data in youth. Diabetes Ther 2019 Apr;10(2):751-755. [doi: 10.1007/s13300-019-0571-0] [Medline: 30701468]

97. Kahkoska AR, Adair LA, Aiello AE, Burger KS, Buse JB, Crandell J, et al. Identification of clinically relevant dysglycemia phenotypes based on continuous glucose monitoring data from youth with type 1 diabetes and elevated hemoglobin A1c. Pediatr Diabetes 2019 Aug;20(5):556-566 [FREE Full text] [doi: 10.1111/pedi.12856] [Medline: $\underline{30972889}$ ]

98. Piona C, Marigliano M, Mozzillo E, Franzese A, Zanfardino A, Iafusco D, et al. Long-term glycemic control and glucose variability assessed with continuous glucose monitoring in a pediatric population with type 1 diabetes: determination of optimal sampling duration. Pediatr Diabetes 2020 Dec;21(8):1485-1492. [doi: 10.1111/pedi.13115] [Medline: 32935887]

99. Helminen O, Pokka T, Tossavainen P, Ilonen J, Knip M, Veijola R. Continuous glucose monitoring and HbA1c in the evaluation of glucose metabolism in children at high risk for type 1 diabetes mellitus. Diabetes Res Clin Pract 2016 Oct;120:89-96. [doi: 10.1016/j.diabres.2016.07.027] [Medline: 27525364]

100. Steck AK, Dong F, Taki I, Hoffman M, Klingensmith GJ, Rewers MJ. Early hyperglycemia detected by continuous glucose monitoring in children at risk for type 1 diabetes. Diabetes Care 2014 Jul;37(7):2031-2033 [FREE Full text] [doi: 10.2337/dc13-2965] [Medline: 24784826]

101. Steck AK, Dong F, Taki I, Hoffman M, Simmons K, Frohnert BI, et al. Continuous glucose monitoring predicts progression to diabetes in autoantibody positive children. J Clin Endocrinol Metab 2019 Aug 01;104(8):3337-3344 [FREE Full text] [doi: 10.1210/jc.2018-02196] [Medline: 30844073] 
102. Buckingham B, Cheng P, Beck RW, Kollman C, Ruedy KJ, Weinzimer SA, Diabetes Research in Children Network (DirecNet)Type 1 Diabetes TrialNet Study Groups. CGM-measured glucose values have a strong correlation with C-peptide, HbA1c and IDAAC, but do poorly in predicting C-peptide levels in the two years following onset of diabetes. Diabetologia 2015 Jun;58(6):1167-1174 [FREE Full text] [doi: 10.1007/s00125-015-3559-y] [Medline: 25773405]

103. Ferenci T, Körner A, Kovács L. The interrelationship of HbA1c and real-time continuous glucose monitoring in children with type 1 diabetes. Diabetes Res Clin Pract 2015 Apr;108(1):38-44. [doi: 10.1016/j.diabres.2015.01.019] [Medline: 25666106]

104. Beck R, Steffes M, Xing D, Ruedy K, Mauras N, Wilson DM, Diabetes Research in Children Network (DirecNet) Study Group. The interrelationships of glycemic control measures: HbA1c, glycated albumin, fructosamine, 1,5-anhydroglucitrol, and continuous glucose monitoring. Pediatr Diabetes 2011 Dec;12(8):690-695 [FREE Full text] [doi: 10.1111/j.1399-5448.2011.00764.x] [Medline: 21496193]

105. Wilson DM, Xing D, Cheng J, Beck RW, Hirsch I, Kollman C, Juvenile Diabetes Research Foundation Continuous Glucose Monitoring Study Group. Persistence of individual variations in glycated hemoglobin: analysis of data from the Juvenile Diabetes Research Foundation continuous glucose monitoring randomized trial. Diabetes Care 2011 Jun;34(6):1315-1317 [FREE Full text] [doi: 10.2337/dc10-1661] [Medline: 21505208]

106. Chan CL, Pyle L, Morehead R, Baumgartner A, Cree-Green M, Nadeau KJ. The role of glycemia in insulin resistance in youth with type 1 and type 2 diabetes. Pediatr Diabetes 2017 Sep;18(6):470-477 [FREE Full text] [doi: 10.1111/pedi.12422] [Medline: 27503277]

107. Juvenile Diabetes Research Foundation Continuous Glucose Monitoring Study Group, Fiallo-Scharer R, Cheng J, Beck RW, Buckingham BA, Chase HP, et al. Factors predictive of severe hypoglycemia in type 1 diabetes: analysis from the Juvenile Diabetes Research Foundation continuous glucose monitoring randomized control trial dataset. Diabetes Care 2011 Mar;34(3):586-590 [FREE Full text] [doi: 10.2337/dc10-1111] [Medline: 21266651]

108. Elkon-Tamir E, Lebenthal Y, Laurian I, Dorfman A, Chorna E, Interator H, et al. Type 1 diabetes outcomes of children born in Israel of Eritrean asylum seekers. Acta Diabetol 2021 Feb;58(2):145-152. [doi: 10.1007/s00592-020-01597-3] [Medline: 32915299]

109. Patton SR, Williams LB, Eder SJ, Crawford MJ, Dolan L, Powers SW. Use of continuous glucose monitoring in young children with type 1 diabetes: implications for behavioral research. Pediatr Diabetes 2011 Feb;12(1):18-24 [FREE Full text] [doi: 10.1111/j.1399-5448.2010.00649.x] [Medline: 20337971]

110. Sherr J, Tamborlane WV, Xing D, Tsalikian E, Mauras N, Buckingham B, Diabetes Research in Children Network (DirecNet) Study Group. Achievement of target A1C levels with negligible hypoglycemia and low glucose variability in youth with short-term type 1 diabetes and residual $\beta$-cell function. Diabetes Care 2012 Apr;35(4):817-820 [FREE Full text] [doi: 10.2337/dc11-2190] [Medline: 22323414]

111. Choleau C, Aubert C, Cahané M, Reach G. High day-to-day glucose variability: a frequent phenomenon in children and adolescents with type 1 diabetes attending summer camp. Diabetes Metab 2008 Feb;34(1):46-51. [doi:

10.1016/j.diabet.2007.12.002] [Medline: 18206413]

112. Patton SR, Midyett LK, Dolan LM, Powers SW. A comparison of average daily risk range scores for young children with type 1 diabetes mellitus using continuous glucose monitoring and self-monitoring data. Diabetes Technol Ther 2012 Mar;14(3):239-243 [FREE Full text] [doi: 10.1089/dia.2011.0169] [Medline: 22047051]

113. Zhu J, Volkening LK, Laffel LM. Distinct patterns of daily glucose variability by pubertal status in youth with type 1 diabetes. Diabetes Care 2020 Jan;43(1):22-28 [FREE Full text] [doi: 10.2337/dc19-0083] [Medline: 31308020]

114. Gandrud LM, Xing D, Kollman C, Block JM, Kunselman B, Wilson DM, et al. The Medtronic Minimed Gold continuous glucose monitoring system: an effective means to discover hypo- and hyperglycemia in children under 7 years of age. Diabetes Technol Ther 2007 Aug;9(4):307-316. [doi: 10.1089/dia.2007.0026] [Medline: 17705686]

115. Juvenile Diabetes Research Foundation Continuous Glucose Monitoring Study Group. Prolonged nocturnal hypoglycemia is common during 12 months of continuous glucose monitoring in children and adults with type 1 diabetes. Diabetes Care 2010 May;33(5):1004-1008 [FREE Full text] [doi: 10.2337/dc09-2081] [Medline: 20200306]

116. Sundberg F, Forsander G. Detection and treatment efficacy of hypoglycemic events in the everyday life of children younger than 7 yr. Pediatr Diabetes 2014 Feb;15(1):34-40. [doi: 10.1111/pedi.12057] [Medline: 23809540]

117. Lipsky LM, Gee B, Liu A, Nansel TR. Glycemic control and variability in association with body mass index and body composition over 18months in youth with type 1 diabetes. Diabetes Res Clin Pract 2016 Oct;120:97-103 [FREE Full text] [doi: 10.1016/j.diabres.2016.07.028] [Medline: 27525365]

118. Hoffman RP, Dye AS, Huang H, Bauer JA. Glycemic variability predicts inflammation in adolescents with type 1 diabetes. J Pediatr Endocrinol Metab 2016 Oct 01;29(10):1129-1133 [FREE Full text] [doi: 10.1515/jpem-2016-0139] [Medline: 27658133]

119. Pulkkinen MA, Tuomaala AK, Hero M, Gordin D, Sarkola T. Motivational Interview to improve vascular health in Adolescents with poorly controlled type 1 Diabetes (MIAD): a randomized controlled trial. BMJ Open Diabetes Res Care $2020 \mathrm{Jul}$;8(1):e001216 [FREE Full text] [doi: 10.1136/bmjdrc-2020-001216] [Medline: 32723754] 
120. Barnea-Goraly N, Raman M, Mazaika P, Marzelli M, Hershey T, Weinzimer SA, Diabetes Research in Children Network (DirecNet). Alterations in white matter structure in young children with type 1 diabetes. Diabetes Care 2014 Feb;37(2):332-340 [FREE Full text] [doi: 10.2337/dc13-1388] [Medline: 24319123]

121. DeSalvo DJ, Miller KM, Hermann JM, Maahs DM, Hofer SE, Clements MA, T1D ExchangeDPV Registries. Continuous glucose monitoring and glycemic control among youth with type 1 diabetes: international comparison from the T1D Exchange and DPV Initiative. Pediatr Diabetes 2018 Nov;19(7):1271-1275 [FREE Full text] [doi: 10.1111/pedi.12711] [Medline: 29923262]

122. Chase HP, Beck RW, Xing D, Tamborlane WV, Coffey J, Fox LA, et al. Continuous glucose monitoring in youth with type 1 diabetes: 12-month follow-up of the Juvenile Diabetes Research Foundation continuous glucose monitoring randomized trial. Diabetes Technol Ther 2010 Jul;12(7):507-515. [doi: 10.1089/dia.2010.0021] [Medline: 20597824]

123. Burckhardt M, Abraham MB, Mountain J, Coenen D, Paniora J, Clapin H, et al. Improvement in psychosocial outcomes in children with type 1 diabetes and their parents following subsidy for continuous glucose monitoring. Diabetes Technol Ther 2019 Oct;21(10):575-580. [doi: 10.1089/dia.2019.0149] [Medline: 31335192]

124. Addala A, Maahs DM, Scheinker D, Chertow S, Leverenz B, Prahalad P. Uninterrupted continuous glucose monitoring access is associated with a decrease in HbA1c in youth with type 1 diabetes and public insurance. Pediatr Diabetes 2020 Nov;21(7):1301-1309. [doi: 10.1111/pedi.13082] [Medline: 32681582]

125. Deiss D, Bolinder J, Riveline J, Battelino T, Bosi E, Tubiana-Rufi N, et al. Improved glycemic control in poorly controlled patients with type 1 diabetes using real-time continuous glucose monitoring. Diabetes Care 2006 Dec;29(12):2730-2732. [doi: 10.2337/dc06-1134] [Medline: 17130215]

126. Deiss D, Hartmann R, Schmidt J, Kordonouri O. Results of a randomised controlled cross-over trial on the effect of continuous subcutaneous glucose monitoring (CGMS) on glycaemic control in children and adolescents with type 1 diabetes. Exp Clin Endocrinol Diabetes 2006 Feb;114(2):63-67. [doi: 10.1055/s-2006-923887] [Medline: 16570235]

127. Diabetes Research in Children Network (DirecNet) Study Group, Buckingham B, Beck RW, Tamborlane WV, Xing D, Kollman C, et al. Continuous glucose monitoring in children with type 1 diabetes. J Pediatr 2007 Oct;151(4):388-93,-393.e1-2 [FREE Full text] [doi: 10.1016/j.jpeds.2007.03.047] [Medline: 17889075]

128. Weinzimer S, Xing D, Tansey M, Fiallo-Scharer R, Mauras N, Wysocki T, Diabetes Research in Children Network (DirecNet) Study Group. FreeStyle navigator continuous glucose monitoring system use in children with type 1 diabetes using glargine-based multiple daily dose regimens: results of a pilot trial Diabetes Research in Children Network (DirecNet) Study Group. Diabetes Care 2008 Mar;31(3):525-527 [FREE Full text] [doi: 10.2337/dc07-1995] [Medline: 18096811]

129. Juvenile Diabetes Research Foundation Continuous Glucose Monitoring Study Group, Tamborlane WV, Beck RW, Bode BW, Buckingham B, Chase HP, et al. Continuous glucose monitoring and intensive treatment of type 1 diabetes. N Engl J Med 2008 Oct 02;359(14):1464-1476. [doi: 10.1056/NEJMoa0805017] [Medline: 18779236]

130. Wong JC, Foster NC, Maahs DM, Raghinaru D, Bergenstal RM, Ahmann AJ, T1D Exchange Clinic Network. Real-time continuous glucose monitoring among participants in the T1D Exchange clinic registry. Diabetes Care 2014 Oct;37(10):2702-2709 [FREE Full text] [doi: 10.2337/dc14-0303] [Medline: 25011947]

131. Giani E, Snelgrove R, Volkening LK, Laffel LM. Continuous Glucose Monitoring (CGM) adherence in youth with type 1 diabetes: associations with biomedical and psychosocial variables. J Diabetes Sci Technol 2017 May;11(3):476-483 [FREE Full text] [doi: 10.1177/1932296816676280] [Medline: 27807014]

132. McGill DE, Volkening LK, Butler DA, Harrington KR, Katz ML, Laffel LM. Baseline psychosocial characteristics predict frequency of continuous glucose monitoring in youth with type 1 diabetes. Diabetes Technol Ther 2018 Jun;20(6):434-439 [FREE Full text] [doi: 10.1089/dia.2018.0037] [Medline: 29727245]

133. Sheikh K, Bartz SK, Lyons SK, DeSalvo DJ. Diabetes device use and glycemic control among youth with type 1 diabetes: a single-center, cross-sectional study. J Diabetes Res 2018;2018:5162162 [FREE Full text] [doi: 10.1155/2018/5162162] [Medline: $\underline{30151393]}$

134. Dovc K, Cargnelutti K, Sturm A, Selb J, Bratina N, Battelino T. Continuous glucose monitoring use and glucose variability in pre-school children with type 1 diabetes. Diabetes Res Clin Pract 2019 Jan;147:76-80 [FREE Full text] [doi: 10.1016/j.diabres.2018.10.005] [Medline: $\underline{\text { 30332618] }}$

135. Patton SR, Noser AE, Youngkin EM, Majidi S, Clements MA. Early initiation of diabetes devices relates to improved glycemic control in children with recent-onset type 1 diabetes mellitus. Diabetes Technol Ther 2019 Jul;21(7):379-384 [FREE Full text] [doi: 10.1089/dia.2019.0026] [Medline: $\underline{\text { 31166808] }}$

136. Nwosu BU, Yeasmin S, Ayyoub S, Rupendu S, Villalobos-Ortiz TR, Jasmin G, et al. Continuous glucose monitoring reduces pubertal hyperglycemia of type 1 diabetes. J Pediatr Endocrinol Metab 2020 Jul 28;33(7):865-872. [doi: 10.1515/jpem-2020-0057] [Medline: 32634109]

137. Cherubini V, Bonfanti R, Casertano A, De Nitto E, Iannilli A, Lombardo F, et al. Time in range in children with type 1 diabetes using treatment strategies based on nonautomated insulin delivery systems in the real world. Diabetes Technol Ther $2020 \mathrm{Jul}$;22(7):509-515. [doi: 10.1089/dia.2020.0031] [Medline: 32073311]

138. Bukara-Radujković G, Zdravković D, Lakić S. Short-term use of continuous glucose monitoring system adds to glycemic control in young type 1 diabetes mellitus patients in the long run: a clinical trial. Vojnosanit Pregl 2011 Aug;68(8):650-654. [doi: 10.2298/vsp1108650b] [Medline: 21991787] 
139. Vesco AT, Jedraszko AM, Garza KP, Weissberg-Benchell J. Continuous glucose monitoring associated with less diabetes-specific emotional distress and lower A1c among adolescents with type 1 diabetes. J Diabetes Sci Technol 2018 Jul;12(4):792-799 [FREE Full text] [doi: 10.1177/1932296818766381] [Medline: 29595061]

140. Raviteja KV, Kumar R, Dayal D, Sachdeva N. Clinical efficacy of professional continuous glucose monitoring in improving glycemic control among children with type 1 diabetes mellitus: an open-label randomized control trial. Sci Rep 2019 Apr 16;9(1):6120 [FREE Full text] [doi: 10.1038/s41598-019-42555-6] [Medline: $\underline{\text { 30992480] }}$

141. Flokas ME, Zeymo A, Mete M, Anhalt H, Rother KI, Gourgari E. Overweight and obese children with optimal control in the T1D Exchange Registry: how are they different from lean children with optimal control? J Diabetes Complications 2020 Apr;34(4):107513 [FREE Full text] [doi: 10.1016/j.jdiacomp.2019.107513] [Medline: $\underline{\text { 32007420] }}$

142. Laffel LM, Kanapka LG, Beck RW, Bergamo K, Clements MA, Criego A, CGM Intervention in TeensYoung Adults with T1D (CITY) Study Group, CDE10. Effect of continuous glucose monitoring on glycemic control in adolescents and young adults with type 1 diabetes: a randomized clinical trial. J Am Med Assoc 2020 Jun 16;323(23):2388-2396 [FREE Full text] [doi: 10.1001/jama.2020.6940] [Medline: 32543683]

143. Lewis KR, McCrone S, Deiriggi P, Bendre S. Effectiveness of continuous glucose monitoring in children, adolescents, and young adults with poorly controlled type 1 diabetes. J Spec Pediatr Nurs 2017 Jan;22(1) [FREE Full text] [doi: 10.1111/jspn.12162] [Medline: 27739620]

144. Wojciechowski P, Ryś P, Lipowska A, Gawęska M, Małecki MT. Efficacy and safety comparison of continuous glucose monitoring and self-monitoring of blood glucose in type 1 diabetes: systematic review and meta-analysis. Pol Arch Med Wewn 2011 Oct;121(10):333-343 [FREE Full text] [Medline: 22045094]

145. Battelino T, Conget I, Olsen B, Schütz-Fuhrmann I, Hommel E, Hoogma R, SWITCH Study Group. The use and efficacy of continuous glucose monitoring in type 1 diabetes treated with insulin pump therapy: a randomised controlled trial. Diabetologia 2012 Dec;55(12):3155-3162 [FREE Full text] [doi: 10.1007/s00125-012-2708-9] [Medline: 22965294]

146. Thabit H, Prabhu JN, Mubita W, Fullwood C, Azmi S, Urwin A, et al. Use of factory-calibrated real-time continuous glucose monitoring improves time in target and $\mathrm{HbA}$ in a multiethnic cohort of adolescents and young adults with type 1 diabetes: the MILLENNIALS study. Diabetes Care 2020 Oct;43(10):2537-2543. [doi: 10.2337/dc20-0736] [Medline: $\underline{32723843]}$

147. Guilmin-Crépon S, Carel J, Schroedt J, Sulmont V, Salmon A, Le Tallec C, et al. Is there an optimal strategy for real-time continuous glucose monitoring in pediatrics? A 12-month French multi-center, prospective, controlled randomized trial (Start-In!). Pediatr Diabetes 2019 May;20(3):304-313. [doi: 10.1111/pedi.12820] [Medline: 30663187]

148. Juvenile Diabetes Research Foundation Continuous Glucose Monitoring Study Group. Effectiveness of continuous glucose monitoring in a clinical care environment: evidence from the Juvenile Diabetes Research Foundation continuous glucose monitoring (JDRF-CGM) trial. Diabetes Care 2010 Jan;33(1):17-22 [FREE Full text] [doi: 10.2337/dc09-1502] [Medline: 19837791]

149. Picard S, Bonnemaison-Gilbert E, Leutenegger E, Barat P. Optimization of insulin regimen and glucose outcomes with short-term real-time continuous glucose monitoring (RT-CGM) in type 1 diabetic children with sub-optimal glucose control on multiple daily injections: the pediatric DIACCOR study. Arch Pediatr 2019 Feb;26(2):95-101. [doi: 10.1016/j.arcped.2018.11.010] [Medline: 30642746]

150. Rasbach LE, Atkins AE, Milaszewski KM, Keady J, Schmidt LM, Volkening LK, et al. Treatment recommendations following 3-day masked continuous glucose monitoring (CGM) in youth with type 1 diabetes. J Diabetes Sci Technol 2014 May;8(3):494-497 [FREE Full text] [doi: 10.1177/1932296814528135] [Medline: 24876612]

151. Hommel E, Olsen B, Battelino T, Conget I, Schütz-Fuhrmann I, Hoogma R, SWITCH Study Group. Impact of continuous glucose monitoring on quality of life, treatment satisfaction, and use of medical care resources: analyses from the SWITCH study. Acta Diabetol 2014 Oct;51(5):845-851 [FREE Full text] [doi: 10.1007/s00592-014-0598-7] [Medline: 25037251]

152. Ly TT, Hewitt J, Davey RJ, Lim EM, Davis EA, Jones TW. Improving epinephrine responses in hypoglycemia unawareness with real-time continuous glucose monitoring in adolescents with type 1 diabetes. Diabetes Care 2011 Jan;34(1):50-52 [FREE Full text] [doi: 10.2337/dc10-1042] [Medline: 20929999]

153. Ng SM, Moore HS, Clemente MF, Pintus D, Soni A. Continuous glucose monitoring in children with type 1 diabetes improves well-being, alleviates worry and fear of hypoglycemia. Diabetes Technol Ther 2019 Mar;21(3):133-137. [doi: 10.1089/dia.2018.0347] [Medline: 30785768]

154. Sandy JL, Nyunt O, Woodhead HJ, Youde LS, Ramjan KA, Jack MM, et al. Sydney Diabetes centre's experience of the Australian Government's roll out of subsidised continuous glucose monitoring for children with type 1 diabetes mellitus. J Paediatr Child Health 2019 Sep;55(9):1056-1062. [doi: 10.1111/jpc.14340] [Medline: 30565355]

155. Jenkins AJ, Krishnamurthy B, Best JD, Cameron FJ, Colman PG, Hamblin PS, et al. An algorithm guiding patient responses to real-time-continuous glucose monitoring improves quality of life. Diabetes Technol Ther 2011 Feb;13(2):105-109. [doi: 10.1089/dia.2010.0139] [Medline: 21284476]

156. Benassi K, Drobny J, Aye T. Real-time continuous glucose monitoring systems in the classroom/school environment. Diabetes Technol Ther 2013 May;15(5):409-412. [doi: 10.1089/dia.2012.0314] [Medline: 23530577] 
157. Barnard KD, Wysocki T, Ully V, Mader JK, Pieber TR, Thabit H, et al. Closing the Loop in Adults, Children and Adolescents With Suboptimally Controlled Type 1 Diabetes Under Free Living Conditions: A Psychosocial Substudy. J Diabetes Sci Technol 2017 Nov;11(6):1080-1088 [FREE Full text] [doi: 10.1177/1932296817702656] [Medline: 28367636]

158. Golicki DT, Golicka D, Groele L, Pankowska E. Continuous Glucose Monitoring System in children with type 1 diabetes mellitus: a systematic review and meta-analysis. Diabetologia 2008 Feb;51(2):233-240. [doi: 10.1007/s00125-007-0884-9] [Medline: 18060380]

159. Raccah D, Sulmont V, Reznik Y, Guerci B, Renard E, Hanaire H, et al. Incremental value of continuous glucose monitoring when starting pump therapy in patients with poorly controlled type 1 diabetes: the RealTrend study. Diabetes Care 2009 Dec;32(12):2245-2250 [FREE Full text] [doi: 10.2337/dc09-0750] [Medline: 19767384]

160. Juvenile Diabetes Research Foundation Continuous Glucose Monitoring Study Group, Beck RW, Lawrence JM, Laffel L, Wysocki T, Xing D, et al. Quality-of-life measures in children and adults with type 1 diabetes: Juvenile Diabetes Research Foundation Continuous Glucose Monitoring randomized trial. Diabetes Care 2010 Oct;33(10):2175-2177 [FREE Full text] [doi: 10.2337/dc10-0331] [Medline: 20696865]

161. Mauras N, Beck R, Xing D, Ruedy K, Buckingham B, Tansey M, Diabetes Research in Children Network (DirecNet) Study Group. A randomized clinical trial to assess the efficacy and safety of real-time continuous glucose monitoring in the management of type 1 diabetes in young children aged 4 to <10 years.. Diabetes Care 2012 Feb;35(2):204-210 [FREE Full text] [doi: 10.2337/dc11-1746] [Medline: 22210571]

162. Ludwig-Seibold CU, Holder M, Rami B, Raile K, Heidtmann B, Holl RW, German Working Group for insulin pump treatment in pediatric patients, German BMBF Competence Network Diabetes. Continuous glucose monitoring in children, adolescents, and adults with type 1 diabetes mellitus: analysis from the prospective DPV diabetes documentation and quality management system from Germany and Austria. Pediatr Diabetes 2012 Feb;13(1):12-14. [doi:

10.1111/j.1399-5448.2011.00835.x] [Medline: 22128781]

163. Tsalikian E, Fox L, Weinzimer S, Buckingham B, White NH, Beck R, Diabetes Research in Children Network Study Group. Feasibility of prolonged continuous glucose monitoring in toddlers with type 1 diabetes. Pediatr Diabetes 2012 Jun;13(4):301-307 [FREE Full text] [doi: 10.1111/j.1399-5448.2011.00837.x] [Medline: 22151826]

164. Prahalad P, Addala A, Buckingham BA, Wilson DM, Maahs DM. Sustained continuous glucose monitor use in low-income youth with type 1 diabetes following insurance coverage supports expansion of continuous glucose monitor coverage for all. Diabetes Technol Ther 2018 Sep;20(9):632-634 [FREE Full text] [doi: 10.1089/dia.2018.0204] [Medline: 30020810]

165. Swaney EE, McCombe J, Coggan B, Donath S, O'Connell MA, Cameron FJ. Has subsidized continuous glucose monitoring improved outcomes in pediatric diabetes? Pediatr Diabetes 2020 Nov;21(7):1292-1300. [doi: 10.1111/pedi.13106] [Medline: 32829528]

166. Benkhadra K, Alahdab F, Tamhane S, Wang Z, Prokop LJ, Hirsch IB, et al. Real-time continuous glucose monitoring in type 1 diabetes: a systematic review and individual patient data meta-analysis. Clin Endocrinol (Oxf) 2017 Mar;86(3):354-360. [doi: 10.1111/cen.13290] [Medline: 27978595]

167. Szypowska A, Ramotowska A, Dzygalo K, Golicki D. Beneficial effect of real-time continuous glucose monitoring system on glycemic control in type 1 diabetic patients: systematic review and meta-analysis of randomized trials. Eur J Endocrinol 2012 Apr;166(4):567-574. [doi: 10.1530/EJE-11-0642] [Medline: 22096111]

168. Juvenile Diabetes Research Foundation Continuous Glucose Monitoring Study Group, Beck RW, Buckingham B, Miller $\mathrm{K}$, Wolpert H, Xing D, et al. Factors predictive of use and of benefit from continuous glucose monitoring in type 1 diabetes. Diabetes Care 2009 Nov;32(11):1947-1953 [FREE Full text] [doi: 10.2337/dc09-0889] [Medline: 19675206]

169. Rasbach LE, Volkening LK, Markowitz JT, Butler DA, Katz ML, Laffel LM. Youth and parent measures of self-efficacy for continuous glucose monitoring: survey psychometric properties. Diabetes Technol Ther 2015 May;17(5):327-334 [FREE Full text] [doi: 10.1089/dia.2014.0366] [Medline: 25695341]

170. Vazeou A. Continuous blood glucose monitoring in diabetes treatment. Diabetes Res Clin Pract 2011 Aug;93 Suppl 1:125-130. [doi: 10.1016/S0168-8227(11)70028-6] [Medline: 21864744]

171. Ramchandani N, Arya S, Ten S, Bhandari S. Real-life utilization of real-time continuous glucose monitoring: the complete picture. J Diabetes Sci Technol 2011 Jul 01;5(4):860-870 [FREE Full text] [doi: 10.1177/193229681100500407] [Medline: 21880227]

172. Diabetes Research in Children Network (DirecNet) Study Group. Youth and parent satisfaction with clinical use of the GlucoWatch G2 Biographer in the management of pediatric type 1 diabetes. Diabetes Care 2005 Aug;28(8):1929-1935 [FREE Full text] [doi: 10.2337/diacare.28.8.1929] [Medline: 16043734]

173. Buckingham B, Block J, Burdick J, Kalajian A, Kollman C, Choy M, et al. Response to nocturnal alarms using a real-time glucose sensor. Diabetes Technol Ther 2005 Jun;7(3):440-447. [doi: 10.1089/dia.2005.7.440]

174. Hilliard ME, Levy W, Anderson BJ, Whitehouse AL, Commissariat PV, Harrington KR, et al. Benefits and barriers of continuous glucose monitoring in young children with type 1 diabetes. Diabetes Technol Ther 2019 Sep 01;21(9):493-498. [doi: 10.1089/dia.2019.0142]

175. Slover RH. Continuous glucose monitoring in children and adolescents. Curr Diab Rep 2012 Oct;12(5):510-516. [doi: 10.1007/s11892-012-0303-6] [Medline: 22791108] 
176. Berg AK, Olsen BS, Thyssen JP, Zachariae C, Simonsen AB, Pilgaard K, et al. High frequencies of dermatological complications in children using insulin pumps or sensors. Pediatr Diabetes 2018 Jun;19(4):733-740. [doi: 10.1111/pedi.12652] [Medline: 29484783]

177. Messer LH, Tanenbaum ML, Cook PF, Wong JJ, Hanes SJ, Driscoll KA, et al. Cost, hassle, and on-body experience: barriers to diabetes device use in adolescents and potential intervention targets. Diabetes Technol Ther 2020 Oct;22(10):760-767. [doi: 10.1089/dia.2019.0509] [Medline: 32163719]

178. Rigo RS, Levin LE, Belsito DV, Garzon MC, Gandica R, Williams KM. Cutaneous reactions to continuous glucose monitoring and continuous subcutaneous insulin infusion devices in type 1 diabetes mellitus. J Diabetes Sci Technol 2020 May 09. [doi: 10.1177/1932296820918894] [Medline: 32389062]

179. Englert K, Ruedy K, Coffey J, Caswell K, Steffen A, Levandoski L, Diabetes Research in Children (DirecNet) Study Group. Skin and adhesive issues with continuous glucose monitors: a sticky situation. J Diabetes Sci Technol 2014 Jul;8(4):745-751 [FREE Full text] [doi: 10.1177/1932296814529893] [Medline: 24876416]

180. Wadwa RP, Fiallo-Scharer R, Vanderwel B, Messer LH, Cobry E, Chase HP. Continuous glucose monitoring in youth with type 1 diabetes. Diabetes Technol Ther 2009 Jun;11 Suppl 1:83-91. [doi: 10.1089/dia.2008.0122] [Medline: 19469682]

181. Marks BE, Wolfsdorf JI. Monitoring of pediatric type 1 diabetes. Front Endocrinol (Lausanne) 2020;11:128 [FREE Full text] [doi: 10.3389/fendo.2020.00128] [Medline: 32256447]

182. Farfel A, Liberman A, Yackobovitch-Gavan M, Phillip M, Nimri R. Executive functions and adherence to continuous glucose monitoring in children and adolescents with type 1 diabetes. Diabetes Technol Ther 2020 Apr;22(4):265-270. [doi: 10.1089/dia.2019.0341] [Medline: 31789577]

183. Messer L, Ruedy K, Xing D, Coffey J, Englert K, Caswell K, et al. Educating families on real time continuous glucose monitoring: the DirecNet navigator pilot study experience. Diabetes Educ 2009;35(1):124-135 [FREE Full text] [doi: 10.1177/0145721708325157] [Medline: 19244568]

184. Krishna J, Mashaqi S. Actigraphy. In: Encyclopedia of the Neurological Sciences (Second Edition). Amsterdam: Elsevier; 2014:19-23.

185. Reutrakul S, Thakkinstian A, Anothaisintawee T, Chontong S, Borel A, Perfect MM, et al. Sleep characteristics in type 1 diabetes and associations with glycemic control: systematic review and meta-analysis. Sleep Med 2016 Jul;23:26-45 [FREE Full text] [doi: 10.1016/j.sleep.2016.03.019] [Medline: 27692274]

186. Walia H, Mehra R. Practical aspects of actigraphy and approaches in clinical and research domains. Handb Clin Neurol 2019;160:371-379. [doi: 10.1016/B978-0-444-64032-1.00024-2] [Medline: 31277861]

187. Martin JL, Hakim AD. Wrist actigraphy. Chest 2011 Jun;139(6):1514-1527 [FREE Full text] [doi: 10.1378/chest.10-1872] [Medline: 21652563]

188. Meltzer LJ, Montgomery-Downs HE, Insana SP, Walsh CM. Use of actigraphy for assessment in pediatric sleep research. Sleep Med Rev 2012 Oct;16(5):463-475 [FREE Full text] [doi: 10.1016/j.smrv.2011.10.002] [Medline: 22424706]

189. Frye SS, Perfect MM, Silva GE. Diabetes management mediates the association between sleep duration and glycemic control in youth with type 1 diabetes mellitus. Sleep Med 2019 Aug;60:132-138. [doi: 10.1016/j.sleep.2019.01.043] [Medline: 30904394]

190. Patel NJ, Savin KL, Kahanda SN, Malow BA, Williams LA, Lochbihler G, et al. Sleep habits in adolescents with type 1 diabetes: variability in sleep duration linked with glycemic control. Pediatr Diabetes 2018 Apr 30 [FREE Full text] [doi: 10.1111/pedi.12689] [Medline: 29708297]

191. Feeley CA, Sereika SM, Chasens ER, Siminerio L, Charron-Prochownik D, Muzumdar RH, et al. Sleep in parental caregivers and children with type 1 diabetes. J Sch Nurs 2019 Jul 31. [doi: 10.1177/1059840519865942] [Medline: 31366301]

192. Elrokhsi SH, Bluez GP, Chin CN, Wheeler MD, Silva GE, Perfect MM. Differences in sleep architecture according to body mass index in children with type 1 diabetes. Pediatr Diabetes 2020 Feb;21(1):98-105. [doi: 10.1111/pedi.12918] [Medline: $\underline{31498940]}$

193. Monzon AD, Marker AM, Noser AE, Clements MA, Patton SR. Associations between objective sleep behaviors and blood glucose variability in young children with type 1 diabetes. Ann Behav Med 2021 Mar 16;55(2):144-154. [doi: 10.1093/abm/kaaa040] [Medline: $\underline{32542309}$ ]

194. Griggs S, Redeker NS, Jeon S, Grey M. Daily variations in sleep and glucose in adolescents with type 1 diabetes. Pediatr Diabetes 2020 Dec;21(8):1493-1501. [doi: 10.1111/pedi.13117] [Medline: 32902901]

195. Rechenberg K, Griggs S, Jeon S, Redeker N, Yaggi HK, Grey M. Sleep and glycemia in youth with type 1 diabetes. J Pediatr Health Care 2020;34(4):315-324. [doi: 10.1016/j.pedhc.2019.12.002] [Medline: 32171612]

196. Jaser SS, Lord JH, Simmons JH, Malow BA. Brief report: sleep disturbances in young children with type 1 diabetes. Diabetes Res Clin Pract 2016 Oct;120:232-234 [FREE Full text] [doi: 10.1016/j.diabres.2016.08.012] [Medline: 27599087]

197. Jaser SS, Hamburger ER, Bergner EM, Williams R, Slaughter JC, Simmons JH, et al. Sleep coach intervention for teens with type 1 diabetes: randomized pilot study. Pediatr Diabetes 2020 May;21(3):473-478. [doi: 10.1111/pedi.12991] [Medline: $\underline{32003520}$ ]

198. Perfect MM, Beebe D, Levine-Donnerstein D, Frye SS, Bluez GP, Quan SF. The development of a clinically relevant sleep modification protocol for youth with type 1 diabetes. Clin Pract Pediatr Psychol 2016 Jun;4(2):227-240 [FREE Full text] [doi: 10.1037/cpp0000145] [Medline: 27747146] 
199. Kay M. mHealth: new horizons for health through mobile technologies. Geneva, Switzerland: World Health Organization; 2011. URL: https://www.who.int/ehealth/mhealth summit.pdf [accessed 2021-04-27]

200. Cobry EC, Hamburger E, Jaser SS. Impact of the hybrid closed-loop system on sleep and quality of life in youth with type 1 diabetes and their parents. Diabetes Technol Ther 2020 Nov;22(11):794-800. [doi: 10.1089/dia.2020.0057] [Medline: 32212971]

201. Patel SS, Daniels SR. Ambulatory blood pressure monitoring in pediatrics. Curr Hypertens Rep 2019 Jul 26;21(9):71. [doi: 10.1007/s11906-019-0976-1] [Medline: 31350605]

202. Grossman E. Ambulatory blood pressure monitoring in the diagnosis and management of hypertension. Diabetes Care 2013 Aug;36 Suppl 2:307-311 [FREE Full text] [doi: 10.2337/dcS13-2039] [Medline: 23882064]

203. Suláková T, Janda J, Cerná J, Janstová V, Suláková A, Slaný J, et al. Arterial HTN in children with T1DM-frequent and not easy to diagnose. Pediatr Diabetes 2009 Nov;10(7):441-448. [doi: 10.1111/j.1399-5448.2009.00514.x] [Medline: $\underline{19500279]}$

204. Kollias A, Dafni M, Poulidakis E, Ntineri A, Stergiou GS. Out-of-office blood pressure and target organ damage in children and adolescents: a systematic review and meta-analysis. J Hypertens 2014 Dec;32(12):2315-31; discussion 2331. [doi: 10.1097/HJH.0000000000000384] [Medline: 25304469]

205. Downie ML, Ulrich EH, Noone DG. An update on hypertension in children with type 1 diabetes. Can J Diabetes 2018 Apr;42(2):199-204. [doi: 10.1016/j.jcjd.2018.02.008] [Medline: 29602408]

206. Pellizzari M, Speiser PW, Carey DE, Fort P, Kreitzer PM, Frank GR. Twenty-four hour ambulatory blood pressure monitoring in adolescents with type 1 diabetes: getting started. J Diabetes Sci Technol 2008 Nov;2(6):1087-1093 [FREE Full text] [doi: 10.1177/193229680800200617] [Medline: 19885297]

207. Atabek ME, Akyürek N, Eklioglu BS, Alp H. Impaired systolic blood dipping and nocturnal hypertension: an independent predictor of carotid intima-media thickness in type 1 diabetic patients. J Diabetes Complications 2014;28(1):51-55. [doi: 10.1016/j.jdiacomp.2013.09.007] [Medline: 24157221]

208. Chatterjee M, Speiser PW, Pellizzarri M, Carey DE, Fort P, Kreitzer PM, et al. Poor glycemic control is associated with abnormal changes in 24-hour ambulatory blood pressure in children and adolescents with type 1 diabetes mellitus. J Pediatr Endocrinol Metab 2009 Nov;22(11):1061-1067. [doi: 10.1515/jpem.2009.22.11.1061] [Medline: 20101892]

209. Dost A, Klinkert C, Kapellen T, Lemmer A, Naeke A, Grabert M, et al. Arterial hypertension determined by ambulatory blood pressure profiles: contribution to microalbuminuria risk in a multicenter investigation in 2,105 children and adolescents with type 1 diabetes. Diabetes Care 2008 Apr;31(4):720-725. [doi: 10.2337/dc07-0824] [Medline: 18174497]

210. Glackin S, Islam N, Henderson AM, Dionne JM, Harris KC, Panagiotopoulos C, et al. Ambulatory blood pressure and carotid intima media thickness in children with type 1 diabetes. Pediatr Diabetes 2020 Mar;21(2):358-365. [doi: 10.1111/pedi.12960] [Medline: $\underline{31825119}$ ]

211. Horoz OO, Yuksel B, Bayazit AK, Attila G, Sertdemir Y, Mungan NO, et al. Ambulatory blood pressure monitoring and serum nitric oxide concentration in type 1 diabetic children. Endocr J 2009;56(3):477-485 [FREE Full text] [doi: $\underline{10.1507 / e n d o c r j . k 08 \mathrm{e}-338]}$ [Medline: 19225212]

212. Kir M, Cetin B, Demir K, Y1lmaz N, Kızılca O, Demircan T, et al. Can ambulatory blood pressure monitoring detect early diastolic dysfunction in children with type 1 diabetes mellitus: correlations with B-type natriuretic peptide and tissue Doppler findings. Pediatr Diabetes 2016 Feb;17(1):21-27. [doi: 10.1111/pedi.12234] [Medline: 25384349]

213. Lee SH, Kim JH, Kang MJ, Lee YA, Won Yang S, Shin CH. Implications of nocturnal hypertension in children and adolescents with type 1 diabetes. Diabetes Care 2011 Oct;34(10):2180-2185 [FREE Full text] [doi: 10.2337/dc11-0830] [Medline: 21911774]

214. Maggio AB, Farpour-Lambert NJ, Montecucco F, Pelli G, Marchand LM, Schwitzgebel V, et al. Elevated E-selectin and diastolic blood pressure in diabetic children. Eur J Clin Invest 2012 Mar;42(3):303-309. [doi: 10.1111/j.1365-2362.2011.02583.x] [Medline: 21880038]

215. Shalaby NM, Shalaby NM. Study of ambulatory blood pressure in diabetic children: prediction of early renal insult. Ther Clin Risk Manag 2015;11:1531-1537 [FREE Full text] [doi: 10.2147/TCRM.S87751] [Medline: 26491340]

216. Suláková T, Janda J, Cerná J, Janštová V, Feber J. Assessment of arterial stiffness from ambulatory blood pressure monitoring in children with diabetes mellitus type-1 (DMT1). J Hum Hypertens 2012 Jun;26(6):357-364. [doi: 10.1038/jhh.2011.38] [Medline: 21544085]

217. Giacchi V, Timpanaro T, Lo Presti D, Passanisi S, Mattia C, Betta P, et al. Prehypertension in adolescents with cardiovascular risk: a comparison between type 1 diabetic patients and overweight subjects. BMC Res Notes 2016 Feb 24;9:122 [FREE Full text] [doi: 10.1186/s13104-016-1839-3] [Medline: 26911143]

218. Basiratnia M, Abadi SF, Amirhakimi GH, Karamizadeh Z, Karamifar H. Ambulatory blood pressure monitoring in children and adolescents with type- 1 diabetes mellitus and its relation to diabetic control and microalbuminuria. Saudi J Kidney Dis Transpl 2012 Mar;23(2):311-315 [FREE Full text] [Medline: 22382225]

219. Demir K, Abaci A, Küme T, Altincik A, Catli G, Böber E. Evaluation of neutrophil gelatinase-associated lipocalin in normoalbuminuric normotensive type 1 diabetic adolescents. J Pediatr Endocrinol Metab 2012;25(5-6):517-523. [Medline: 22876548] 
220. Perrin NE, Torbjörnsdotter T, Jaremko GA, Berg UB. Risk markers of future microalbuminuria and hypertension based on clinical and morphological parameters in young type 1 diabetes patients. Pediatr Diabetes 2010 Aug;11(5):305-313. [doi: 10.1111/j.1399-5448.2009.00595.x] [Medline: 19761528]

221. Hosking SP, Bhatia R, Crock PA, Wright I, Squance ML, Reeves G. Non-invasive detection of microvascular changes in a paediatric and adolescent population with type 1 diabetes: a pilot cross-sectional study. BMC Endocr Disord 2013 Oct 05;13:41 [FREE Full text] [doi: 10.1186/1472-6823-13-41] [Medline: 24093770]

222. Dost A, Pozza SB, Bollow E, Kovacic R, Vogel P, Feldhahn L, Initiative DPV. Blood pressure regulation determined by ambulatory blood pressure profiles in children and adolescents with type 1 diabetes mellitus: impact on diabetic complications. Pediatr Diabetes 2017 Dec;18(8):874-882. [doi: 10.1111/pedi.12502] [Medline: 28117539]

223. Obermannova B, Petruzelkova L, Sulakova T, Sumnik Z. HbA1c but not diabetes duration predicts increased arterial stiffness in adolescents with poorly controlled type 1 diabetes. Pediatr Diabetes 2017 Jun;18(4):304-310. [doi: 10.1111/pedi.12385] [Medline: 27075550]

224. Gourgari E, Mete M, Dimatulac M, Cogen F, Brady T. Blood pressure during sleep is associated with arterial stiffness and urine microalbumin to creatinine ratio in youth with type 1 diabetes. J Diabetes Complications 2020 Nov;34(11):107678. [doi: 10.1016/j.jdiacomp.2020.107678] [Medline: 32718559]

225. Homhuan W, Poomthavorn P, Paksi W, Khlairit P, Nongnuch A, Pirojsakul K. Masked hypertension and its associations with glycemic variability metrics in children and adolescents with type 1 diabetes. Pediatr Nephrol 2021 Feb;36(2):379-386. [doi: 10.1007/s00467-020-04720-2] [Medline: 32844291]

226. Saygili S, Canpolat N, Cakir A, Konukoglu D, Turan H, Caliskan S, et al. Factors influencing blood pressure and microalbuminuria in children with type 1 diabetes mellitus: salt or sugar? Pediatr Nephrol 2020 Jul;35(7):1267-1276. [doi: 10.1007/s00467-020-04526-2] [Medline: 32211992]

227. Marcovecchio ML, Tossavainen PH, Acerini CL, Barrett TG, Edge J, Neil A, et al. Maternal but not paternal association of ambulatory blood pressure with albumin excretion in young offspring with type 1 diabetes. Diabetes Care 2010 Feb;33(2):366-371 [FREE Full text] [doi: 10.2337/dc09-1152] [Medline: 19918004]

228. Barkai L, Soós A, Vámosi I. Association of angiotensin-converting enzyme DD genotype with 24-h blood pressure abnormalities in normoalbuminuric children and adolescents with type 1 diabetes. Diabet Med 2005 Aug;22(8):1054-1059. [doi: 10.1111/j.1464-5491.2005.01601.x] [Medline: 16026372]

229. Machnica L, Deja G, Polanska J, Czupryniak L, Szymanska-Garbacz E, Loba J, et al. Blood pressure disturbances and endothelial dysfunction markers in children and adolescents with type 1 diabetes. Atherosclerosis 2014 Nov;237(1):129-134. [doi: 10.1016/j.atherosclerosis.2014.09.006] [Medline: 25238220]

230. Darcan S, Goksen D, Mir S, Serdaroglu E, Buyukinan M, Coker M, et al. Alterations of blood pressure in type 1 diabetic children and adolescents. Pediatr Nephrol 2006 May;21(5):672-676. [doi: 10.1007/s00467-006-0074-x] [Medline: 16568306]

231. Delaney A, Pellizzari M, Speiser PW, Frank GR. Pitfalls in the measurement of the nocturnal blood pressure dip in adolescents with type 1 diabetes. Diabetes Care 2009 Jan;32(1):165-168 [FREE Full text] [doi: 10.2337/dc08-1319] [Medline: 18984777]

232. Pietrzak I, Fendler W, Dróżdż I, Mianowska B, Młynarski W, Szadkowska A. Arterial stiffness, BMI, dipping status and ACE D/I polymorphism in type 1 diabetic children. Exp Clin Endocrinol Diabetes 2016 May;124(5):283-287. [doi: 10.1055/s-0042-101243] [Medline: 27050070]

233. Karavanaki K, Kazianis G, Kakleas K, Konstantopoulos I, Karayianni C. QT interval prolongation in association with impaired circadian variation of blood pressure and heart rate in adolescents with type 1 diabetes. Diabet Med 2007 Nov;24(11):1247-1253. [doi: 10.1111/j.1464-5491.2007.02220.x] [Medline: 17672861]

234. Karavanaki K, Kazianis G, Konstantopoulos I, Tsouvalas E, Karayianni C. Early signs of left ventricular dysfunction in adolescents with type 1 diabetes mellitus: the importance of impaired circadian modulation of blood pressure and heart rate. J Endocrinol Invest 2008 Apr;31(4):289-296. [doi: 10.1007/BF03346360] [Medline: 18475045]

235. Krause M, Rüdiger H, Bald M, Näke A, Paditz E. Autonomic blood pressure control in children and adolescents with type 1 diabetes mellitus. Pediatr Diabetes 2009 Jun;10(4):255-263. [doi: 10.1111/j.1399-5448.2008.00447.x] [Medline: 19207232]

236. Ješić M, Sajić S, Ješić M, Kostić M, Peco-Antić A, Vujnović Z, et al. Microalbuminuria in relation to metabolic control and blood pressure in adolescents with type 1 diabetes. Arch Med Sci 2011 Dec 31;7(6):1037-1041 [FREE Full text] [doi: 10.5114/aoms.2011.26617] [Medline: 22328888]

237. Gallego PH, Gilbey AJ, Grant MT, Bulsara MK, Byme GC, Jones TW, et al. Early changes in 24-hour ambulatory blood pressure are associated with high normal albumin excretion rate in children with type 1 diabetes mellitus. J Pediatr Endocrinol Metab 2005 Sep;18(9):879-885. [doi: 10.1515/jpem.2005.18.9.879] [Medline: 16279366]

238. Soltysiak J, Skowronska B, Fichna P, Ostalska-Nowicka D, Stankiewicz W, Lewandowska-Stachowiak M, et al. Urinary angiotensinogen and urinary sodium are associated with blood pressure in normoalbuminuric children with diabetes. Pediatr Nephrol 2014 Dec;29(12):2373-2378 [FREE Full text] [doi: 10.1007/s00467-014-2861-0] [Medline: 24880819]

239. Lovshin JA, Škrtić M, Bjornstad P, Moineddin R, Daneman D, Dunger D, et al. Hyperfiltration, urinary albumin excretion, and ambulatory blood pressure in adolescents with type 1 diabetes mellitus. Am J Physiol Renal Physiol 2018 Apr 01;314(4):667-674 [FREE Full text] [doi: 10.1152/ajprenal.00400.2017] [Medline: 29357443] 
240. Raes A, Matthys D, Donckerwolcke R, Craen M, Van Aken S, Vande Walle J. Renal functional changes in relation to hemodynamic parameters during exercise test in normoalbuminuric insulin-dependent children. Acta Paediatr 2007 Apr;96(4):548-551. [doi: 10.1111/j.1651-2227.2006.00157.x] [Medline: 17306011]

241. Tadida Meli IH, Tankeu AT, Dehayem MY, Chelo D, Noubiap JJ, Sobngwi E. Exercise-induced albuminuria circadian variations in blood pressure in type 1 diabetes. World J Diabetes 2017 Feb 15;8(2):74-79. [doi: 10.4239/wjd.v8.i2.74] [Medline: 28265345]

242. Soltysiak J, Ostalska-Nowicka D, Maćkowiak-Lewandowicz K, Skowronska B, Fichna P, Stankiewicz W, et al. Early kidney damage in diabetic adolescents with increased blood pressure and glomerular hyperfiltration. Minerva Pediatr 2020 Aug 04. [doi: 10.23736/S0026-4946.20.05812-0] [Medline: 32748608 ]

243. Zhu H, Zheng H, Liu X, Mai W, Huang Y. Clinical applications for out-of-office blood pressure monitoring. Ther Adv Chronic Dis 2020;11:1-11 [FREE Full text] [doi: 10.1177/2040622320901660] [Medline: 32010437]

244. Garritty C, Emam KE. Who's using PDAs? Estimates of PDA use by health care providers: a systematic review of surveys. J Med Internet Res 2006 May 12;8(2):e7 [FREE Full text] [doi: 10.2196/jmir.8.2.e7] [Medline: 16867970]

245. Borus JS, Blood E, Volkening LK, Laffel L, Shrier LA. Momentary assessment of social context and glucose monitoring adherence in adolescents with type 1 diabetes. J Adolesc Health 2013 May;52(5):578-583 [FREE Full text] [doi: 10.1016/j.jadohealth.2012.10.003] [Medline: 23298986]

246. Gonder-Frederick LA, Zrebiec JF, Bauchowitz AU, Ritterband LM, Magee JC, Cox DJ, et al. Cognitive function is disrupted by both hypo- and hyperglycemia in school-aged children with type 1 diabetes: a field study. Diabetes Care 2009 Jun;32(6):1001-1006 [FREE Full text] [doi: 10.2337/dc08-1722] [Medline: 19324943]

247. Gonder-Frederick L, Zrebiec J, Bauchowitz A, Lee J, Cox D, Ritterband L, et al. Detection of hypoglycemia by children with type 1 diabetes 6 to 11 years of age and their parents: a field study. Pediatrics 2008 Mar;121(3):e489-e495. [doi: 10.1542/peds.2007-0808] [Medline: 18310169]

248. Moskowitz DS, Young SN. Ecological momentary assessment: what it is and why it is a method of the future in clinical psychopharmacology. J Psychiatry Neurosci 2006 Jan;31(1):13-20 [FREE Full text] [Medline: 16496031]

249. Barnes TL, Lee S, Thompson N, Mullen K, Chatterton P, Gandrud L. Barriers to glucose testing and attitudes toward mobile app and device use in a large cohort of T1D pediatric patients: implications for diabetes management. J Diabetes Sci Technol 2018 Nov;12(6):1246-1247 [FREE Full text] [doi: 10.1177/1932296818794706] [Medline: 30136595]

250. Mulvaney SA, Vaala SE, Carroll RB, Williams LK, Lybarger CK, Schmidt DC, et al. A mobile app identifies momentary psychosocial and contextual factors related to mealtime self-management in adolescents with type 1 diabetes. J Am Med Inform Assoc 2019 Dec 01;26(12):1627-1631. [doi: 10.1093/jamia/ocz147] [Medline: 31529065]

251. Frøisland DH, Arsand E, Skårderud F. Improving diabetes care for young people with type 1 diabetes through visual learning on mobile phones: mixed-methods study. J Med Internet Res 2012;14(4):e111 [FREE Full text] [doi: 10.2196/jmir.2155] [Medline: 22868871]

252. Amin A, Lau L, Crawford S, Edwards A, Pacaud D. Prospective assessment of hypoglycemia symptoms in children and adults with type 1 diabetes. Can J Diabetes 2014 Aug;38(4):263-268. [doi: 10.1016/j.jcjd.2014.05.007] [Medline: 25023739]

253. Offringa R, Sheng T, Parks L, Clements M, Kerr D, Greenfield MS. Digital diabetes management application improves glycemic outcomes in people with type 1 and type 2 diabetes. J Diabetes Sci Technol 2018 May;12(3):701-708 [FREE Full text] [doi: 10.1177/1932296817747291] [Medline: 29277103]

254. Klee P, Bussien C, Castellsague M, Combescure C, Dirlewanger M, Girardin C, et al. An intervention by a patient-designed do-it-yourself mobile device app reduces HbA1c in children and adolescents with type 1 diabetes: a randomized double-crossover study. Diabetes Technol Ther 2018 Dec;20(12):797-805. [doi: 10.1089/dia.2018.0255] [Medline: 30403495]

255. Prakasam G, Rees C, Lyden M, Parkin CG. Use of a novel smartphone-based diabetes management system improved feelings of confidence and safety and reduced hypoglycemia fear among parents/caregivers of children/adolescents with type 1 diabetes. J Diabetes Sci Technol 2017 Jan;11(1):182-183 [FREE Full text] [doi: 10.1177/1932296816650901] [Medline: 27207891]

256. Wong JC, Neinstein AB, Look H, Arbiter B, Chokr N, Ross C, et al. Pilot study of a novel application for data visualization in type 1 diabetes. J Diabetes Sci Technol 2017 Jul;11(4):800-807 [FREE Full text] [doi: 10.1177/1932296817691305] [Medline: 28617628]

257. Bellfield EJ, Sharp LK, Xia Y, Gerber BS. Use of a mobile app to facilitate blood glucose monitoring in adolescents with type 1 diabetes: single-subject nonrandomized clinical trial. JMIR Diabetes 2018 Feb 07;3(1):e3 [FREE Full text] [doi: 10.2196/diabetes.8357] [Medline: 30291085 ]

258. Clements MA, Staggs VS. A mobile app for synchronizing glucometer data: impact on adherence and glycemic control among youths with type 1 diabetes in routine care. J Diabetes Sci Technol 2017 Dec;11(3):461-467 [FREE Full text] [doi: 10.1177/1932296817691302] [Medline: 28745097]

259. Mulvaney SA, Vaala S, Hood KK, Lybarger C, Carroll R, Williams L, et al. Mobile momentary assessment and biobehavioral feedback for adolescents with type 1 diabetes: feasibility and engagement patterns. Diabetes Technol Ther 2018 Jul;20(7):465-474 [FREE Full text] [doi: 10.1089/dia.2018.0064] [Medline: 29882677]

260. Carroll AE, DiMeglio LA, Stein S, Marrero DG. Using a cell phone-based glucose monitoring system for adolescent diabetes management. Diabetes Educ 2011;37(1):59-66. [doi: 10.1177/0145721710387163] [Medline: 21106908] 
261. Carroll AE, DiMeglio LA, Stein S, Marrero DG. Contracting and monitoring relationships for adolescents with type 1 diabetes: a pilot study. Diabetes Technol Ther 2011 May;13(5):543-549 [FREE Full text] [doi: 10.1089/dia.2010.0181] [Medline: 21406011]

262. Pramanik BK, Angelin JJ, Mathai VJ, Mathai S, Korula S, Simon A. Smartphone app as motivational intervention to improve glycemic control in adolescents with type 1 diabetes. Indian J Pediatr 2019 Dec;86(12):1118-1123. [doi: 10.1007/s12098-019-03035-x] [Medline: 31353430]

263. Gammon D, Arsand E, Walseth OA, Andersson N, Jenssen M, Taylor T. Parent-child interaction using a mobile and wireless system for blood glucose monitoring. J Med Internet Res 2005 Nov 21;7(5):e57 [FREE Full text] [doi: 10.2196/jmir.7.5.e57] [Medline: 16403721$]$

264. Castensøe-Seidenfaden P, Husted GR, Jensen AK, Hommel E, Olsen BS, Pedersen-Bjergaard U, et al. Testing a smartphone app (young with diabetes) to improve self-management of diabetes over 12 months: randomized controlled trial. JMIR Mhealth Uhealth 2018 Jun 26;6(6):e141 [FREE Full text] [doi: 10.2196/mhealth.9487] [Medline: 29945861]

265. Cafazzo JA, Casselman M, Hamming N, Katzman DK, Palmert MR. Design of an mHealth app for the self-management of adolescent type 1 diabetes: a pilot study. J Med Internet Res 2012;14(3):e70 [FREE Full text] [doi: 10.2196/jmir.2058] [Medline: 22564332]

266. Holtz BE, Murray KM, Hershey DD, Dunneback JK, Cotten SR, Holmstrom AJ, et al. Developing a patient-centered mHealth app: a tool for adolescents with type 1 diabetes and their parents. JMIR Mhealth Uhealth 2017 Apr 19;5(4):e53 [FREE Full text] [doi: 10.2196/mhealth.6654] [Medline: 28428167]

267. Rami B, Popow C, Horn W, Waldhoer T, Schober E. Telemedical support to improve glycemic control in adolescents with type 1 diabetes mellitus. Eur J Pediatr 2006 Oct;165(10):701-705. [doi: 10.1007/s00431-006-0156-6] [Medline: 16670859]

268. Herbert LJ, Mehta P, Monaghan M, Cogen F, Streisand R. Feasibility of the SMART project: a text message program for adolescents with type 1 diabetes. Diabetes Spectr 2014 Nov;27(4):265-269 [FREE Full text] [doi: 10.2337/diaspect.27.4.265] [Medline: 25647048]

269. Warnick JL, Westen SC, Albanese-O'Neill A, Filipp SL, Schatz D, Haller MJ, et al. Use of ecological momentary assessment to measure self-monitoring of blood glucose adherence in youth with type 1 diabetes. Diabetes Spectr 2020 Aug;33(3):280-289. [doi: 10.2337/ds19-0041] [Medline: 32848350]

270. Maahs DM, Mayer-Davis E, Bishop FK, Wang L, Mangan M, McMurray RG. Outpatient assessment of determinants of glucose excursions in adolescents with type 1 diabetes: proof of concept. Diabetes Technol Ther 2012 Aug;14(8):658-664 [FREE Full text] [doi: 10.1089/dia.2012.0053] [Medline: 22853720]

271. Mulvaney SA, Rothman RL, Dietrich MS, Wallston KA, Grove E, Elasy TA, et al. Using mobile phones to measure adolescent diabetes adherence. Health Psychol 2012 Jan;31(1):43-50 [FREE Full text] [doi: 10.1037/a0025543] [Medline: 21967662]

272. Mulvaney SA, Anders S, Smith AK, Pittel EJ, Johnson KB. A pilot test of a tailored mobile and web-based diabetes messaging system for adolescents. J Telemed Telecare 2012 Mar;18(2):115-118 [FREE Full text] [doi: 10.1258/jtt.2011.111006] [Medline: 22383802]

273. Hanauer DA, Wentzell K, Laffel N, Laffel LM. Computerized Automated Reminder Diabetes System (CARDS): e-mail and SMS cell phone text messaging reminders to support diabetes management. Diabetes Technol Ther 2009 Feb;11(2):99-106. [doi: 10.1089/dia.2008.0022] [Medline: 19848576]

274. Zhang S, Hamburger E, Kahanda S, Lyttle M, Williams R, Jaser SS. Engagement with a text-messaging intervention improves adherence in adolescents with type 1 diabetes: brief report. Diabetes Technol Ther 2018 May;20(5):386-389 [FREE Full text] [doi: 10.1089/dia.2018.0015] [Medline: 29792749]

275. Bergner EM, Whittemore R, Patel NJ, Savin KL, Hamburger ER, Jaser SS. Participants' experience and engagement in Check it!: a positive psychology intervention for adolescents with type 1 diabetes. Transl Issues Psychol Sci 2018;4(3):215-227 [FREE Full text] [doi: 10.1037/tps0000161] [Medline: $\underline{\text { 30505889] }}$

276. Bin-Abbas B, Jabbari M, Al-Fares A, El-Dali A, Al-Orifi F. Effect of mobile phone short text messages on glycaemic control in children with type 1 diabetes. J Telemed Telecare 2014 Mar 18;20(3):153-156. [doi: 10.1177/1357633x14529244]

277. Jaser SS, Whittemore R, Choi L, Nwosu S, Russell WE. Randomized trial of a positive psychology intervention for adolescents with type 1 diabetes. J Pediatr Psychol 2019 Jun 01;44(5):620-629 [FREE Full text] [doi: 10.1093/jpepsy/jsz006] [Medline: 30840084]

278. Wagner DV, Barry SA, Stoeckel M, Teplitsky L, Harris MA. NICH at its best for diabetes at its worst: texting teens and their caregivers for better outcomes. J Diabetes Sci Technol 2017 May;11(3):468-475 [FREE Full text] [doi: 10.1177/1932296817695337] [Medline: 28745094]

279. Salamon KS, Hains AA, Fleischman KM, Davies WH, Kichler J. Improving adherence in social situations for adolescents with type 1 diabetes mellitus (T1DM): a pilot study. Prim Care Diabetes 2010 Apr;4(1):47-55. [doi: 10.1016/j.pcd.2009.10.003] [Medline: 19926354]

280. Izquierdo R, Morin PC, Bratt K, Moreau Z, Meyer S, Ploutz-Snyder R, et al. School-centered telemedicine for children with type 1 diabetes mellitus. J Pediatr 2009 Sep;155(3):374-379. [doi: 10.1016/j.jpeds.2009.03.014] [Medline: 19464030] 
281. Lehmkuhl HD, Storch EA, Cammarata C, Meyer K, Rahman O, Silverstein J, et al. Telehealth behavior therapy for the management of type 1 diabetes in adolescents. J Diabetes Sci Technol 2010 Jan 01;4(1):199-208 [FREE Full text] [doi: 10.1177/193229681000400125] [Medline: 20167185]

282. Nunn E, King B, Smart C, Anderson D. A randomized controlled trial of telephone calls to young patients with poorly controlled type 1 diabetes. Pediatr Diabetes 2006 Oct;7(5):254-259. [doi: 10.1111/j.1399-5448.2006.00200.x] [Medline: 17054446]

283. Sarteau AC, Crandell J, Seid M, Kichler JC, Maahs DM, Wang J, et al. Characterization of youth goal setting in the self-management of type 1 diabetes and associations with HbA1c: the Flexible Lifestyle Empowering Change trial. Pediatr Diabetes 2020 Nov;21(7):1343-1352. [doi: 10.1111/pedi.13099] [Medline: 32741045]

284. Malik FS, Yi-Frazier JP, Taplin CE, Roth CL, Whitlock KB, Howard W, et al. Improving the care of youth with type 1 diabetes with a novel medical-legal community intervention: the Diabetes Community Care Ambassador Program. Diabetes Educ 2018 Apr;44(2):168-177. [doi: 10.1177/0145721717750346] [Medline: 29320934]

285. Foltynski P, Ladyzynski P, Pankowska E, Mazurczak K. Efficacy of automatic bolus calculator with automatic speech recognition in patients with type 1 diabetes: a randomized cross-over trial. J Diabetes 2018 Feb 09;10(7):600-608. [doi: 10.1111/1753-0407.12641]

286. Schiaffini R, Tagliente I, Carducci C, Ullmann N, Ciampalini P, Lorubbio A, et al. Impact of long-term use of eHealth systems in adolescents with type 1 diabetes treated with sensor-augmented pump therapy. J Telemed Telecare 2016 Jul;22(5):277-281. [doi: 10.1177/1357633X15598425] [Medline: 26289613]

287. Kassai B, Rabilloud M, Bernoux D, Michal C, Riche B, Ginhoux T, et al. Management of adolescents with very poorly controlled type 1 diabetes by nurses: a parallel group randomized controlled trial. Trials 2015 Sep 08;16:399 [FREE Full text] [doi: 10.1186/s13063-015-0923-7] [Medline: 26350209]

288. Ledderer L, Møller A, Fage-Butler A. Adolescents' participation in their healthcare: a sociomaterial investigation of a diabetes app. Digit Health 2019;5 [FREE Full text] [doi: 10.1177/2055207619845448] [Medline: $\underline{31069104]}$

289. Yi-Frazier JP, Cochrane K, Mitrovich C, Pascual M, Buscaino E, Eaton L, et al. Using Instagram as a modified application of photovoice for storytelling and sharing in adolescents with type 1 diabetes. Qual Health Res 2015 Oct;25(10):1372-1382 [FREE Full text] [doi: 10.1177/1049732315583282] [Medline: 25904674]

290. Nesi J. The impact of social media on youth mental health: challenges and opportunities. N C Med J 2020;81(2):116-121 [FREE Full text] [doi: $10.18043 / \mathrm{ncm} .81 .2 .116]$ [Medline: 32132255$]$

291. McDarby V, Hevey D, Cody D. An overview of the role of social network sites in the treatment of adolescent diabetes. Diabetes Technol Ther 2015 Apr;17(4):291-294. [doi: 10.1089/dia.2014.0308] [Medline: 25654161]

292. Erves JC, Mayo-Gamble TL, Malin-Fair A, Boyer A, Joosten Y, Vaughn YC, et al. Needs, priorities, and recommendations for engaging underrepresented populations in clinical research: a community perspective. J Community Health 2017 Jun 3;42(3):472-480 [FREE Full text] [doi: 10.1007/s10900-016-0279-2] [Medline: 27812847]

293. Davis TC, Arnold CL, Mills G, Miele L. A qualitative study exploring barriers and facilitators of enrolling underrepresented populations in clinical trials and biobanking. Front Cell Dev Biol 2019;7:74 [FREE Full text] [doi: 10.3389/fcell.2019.00074] [Medline: 31114788]

294. Borschuk AP, Everhart RS. Health disparities among youth with type 1 diabetes: a systematic review of the current literature. Fam Syst Health 2015 Sep;33(3):297-313. [doi: 10.1037/fsh0000134] [Medline: 25984737]

295. Schools And Staffing Survey (SASS). National Center for Education Statistics. 2007. URL: https://nces.ed.gov/surveys/ sass/tables/sass0708_035_s1s.asp [accessed 2019-11-12]

296. Parent and Family Involvement in education survey of the National Household Education Surveys Program (PFI-NHES 2007, 2012, and 2016). National Center for Education Statistics. 2018. URL: https://nces.ed.gov/programs/digest/d17/tables/ dt17_227.40.asp [accessed 2019-11-12]

297. Gamaldo AA, Allaire JC. Daily fluctuations in everyday cognition: is it meaningful? J Aging Health 2016 Aug 03;28(5):834-849. [doi: 10.1177/0898264315611669] [Medline: 26538267]

298. van Kesteren MT, Rijpkema M, Ruiter DJ, Morris RG, Fernández G. Building on prior knowledge: schema-dependent encoding processes relate to academic performance. J Cogn Neurosci 2014 Oct;26(10):2250-2261. [doi: 10.1162/jocn a 00630] [Medline: 24702454]

299. Alloway TP, Gathercole SE, Willis C, Adams A. A structural analysis of working memory and related cognitive skills in young children. J Exp Child Psychol 2004 Feb;87(2):85-106. [doi: 10.1016/j.jecp.2003.10.002] [Medline: 14757066]

300. Saarikivi KA, Huotilainen M, Tervaniemi M, Putkinen V. Selectively enhanced development of working memory in musically trained children and adolescents. Front Integr Neurosci 2019;13:62 [FREE Full text] [doi: 10.3389/fnint.2019.00062] [Medline: 31780907]

301. Mayes SD, Calhoun SL, Bixler EO, Zimmerman DN. IQ and neuropsychological predictors of academic achievement. Learn Individ Differ 2009 Jun;19(2):238-241. [doi: 10.1016/j.lindif.2008.09.001]

302. Issar T, Tummanapalli SS, Kwai NC, Chiang JC, Arnold R, Poynten AM, et al. Associations between acute glucose control and peripheral nerve structure and function in type 1 diabetes. Diabet Med 2020 Sep;37(9):1553-1560. [doi:

10.1111/dme.14306] [Medline: 32298478] 
303. Butwicka A, Frisén L, Almqvist C, Zethelius B, Lichtenstein P. Risks of psychiatric disorders and suicide attempts in children and adolescents with type 1 diabetes: a population-based cohort study. Diabetes Care 2015 Mar;38(3):453-459 [FREE Full text] [doi: 10.2337/dc14-0262] [Medline: 25650362]

304. Hilliard ME, Powell PW, Anderson BJ. Evidence-based behavioral interventions to promote diabetes management in children, adolescents, and families. Am Psychol 2016 Oct;71(7):590-601 [FREE Full text] [doi: 10.1037/a0040359] [Medline: 27690487]

\author{
Abbreviations \\ ABPM: ambulatory blood pressure monitoring \\ CGM: continuous glucose monitoring \\ DKA: diabetic ketoacidosis \\ EMA: ecological momentary assessment \\ $\mathbf{H b A}_{1 \mathbf{c}}$ : hemoglobin $\mathrm{A}_{1 \mathrm{c}}$ \\ mHealth: mobile health \\ PDA: personal digital assistant \\ SMBG: self-monitored blood glucose \\ T1D: type 1 diabetes \\ WUSTL: Washington University in St. Louis
}

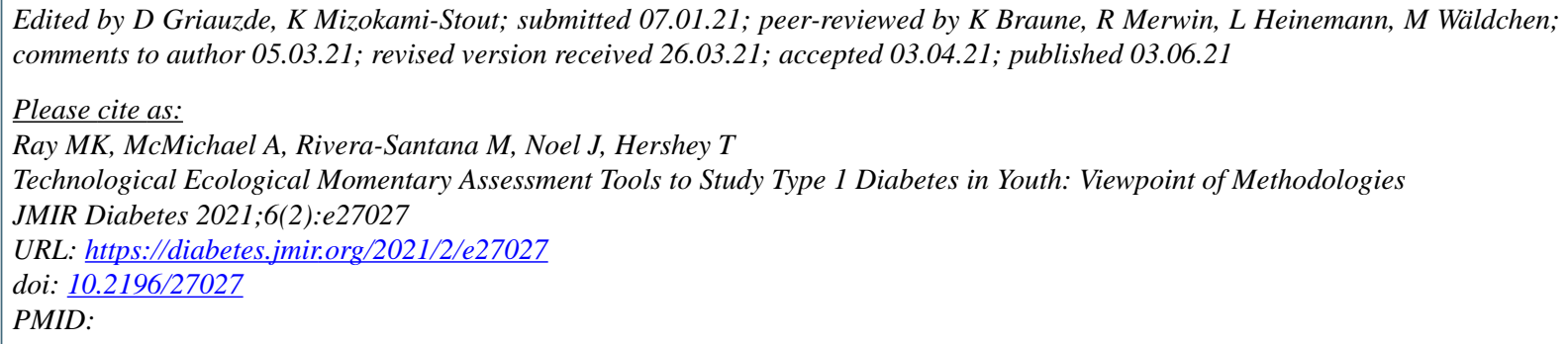

CMary Katherine Ray, Alana McMichael, Maria Rivera-Santana, Jacob Noel, Tamara Hershey. Originally published in JMIR Diabetes (https://diabetes.jmir.org), 03.06.2021. This is an open-access article distributed under the terms of the Creative Commons Attribution License (https://creativecommons.org/licenses/by/4.0/), which permits unrestricted use, distribution, and reproduction in any medium, provided the original work, first published in JMIR Diabetes, is properly cited. The complete bibliographic information, a link to the original publication on https://diabetes.jmir.org/, as well as this copyright and license information must be included. 